\title{
1 Model legumes contribute to faba bean breeding
}

2 Nicolas Rispail ${ }^{1, *}$, Péter Kaló ${ }^{2}$, György B. Kiss ${ }^{2}$, T. H. Noel Ellis ${ }^{3}$, Karine Gallardo ${ }^{4}$,

3 Richard D. Thompson ${ }^{4}$, Elena Prats ${ }^{1}$, Estibaliz Larrainzar ${ }^{5}$, Ruben Ladrera ${ }^{5}$, Esther M.

4 González $^{5}$, Cesar Arrese-Igor ${ }^{5,6}$, Brett J. Ferguson ${ }^{7}$, Peter M. Gresshoff ${ }^{7}$, Diego

$5 \quad$ Rubiales ${ }^{1}$.

6

7

$8{ }^{1}$ Institute for Sustainable Agriculture, CSIC, Alameda del Obispo s/n, 14080 Cordoba,

9 Spain.

10 22Agricultural Biotechnology Center, Gödöllő, Szent-Györgyi A. u. 4. H-2100 Hungary.

$11{ }^{3}$ Department of Crop Genetics, John Innes Centre, Colney Lane, Norwich, NR4 7UH,

12 UK.

$13{ }^{4}$ INRA, UMR 102 Genetics and Ecophysiology of Grain Legumes, 21000 Dijon,

14 France.

$15{ }^{5}$ Dpto. Ciencias del Medio Natural, Universidad Pública de Navarra, Campus Arrosadía,

1631006 Pamplona, Spain

$17{ }^{6}$ Agronomy Physiology Laboratory, Department of Agronomy, University of Florida,

18 POB 110965, Gainesville, FL 32611 USA

$19{ }^{7}$ ARC Centre of Excellence for Integrative Legume Research, the University of

20 Queensland, St. Lucia, Brisbane QLD 4072, Australia

$22 *$ Corresponding author

23 Dr. Nicolas Rispail

24 Institute for Sustainable Agriculture, CSIC,

25 Alameda del Obispo s/n, 
114080 Cordoba, Spain

2 Tel: +34957499213

$3 \quad$ Fax: +34 957499252

$4 \quad$ Email: ge2ririn@uco.es

5 


\section{Abstract}

2 Faba bean is an excellent candidate crop to provide nitrogen input into temperate

3 agricultural systems. However, its growth is hampered by several factors including 4 environmental stresses and the presence of anti-nutritional factors. To solve these

5 limitations, breeding programs have been initiated that were successful for monogenic

6 traits but not so for multigenic traits. The large genome size of faba bean has slowed

7 down breeding processes. Several other legumes have emerged as model legumes

8 including Medicago truncatula, Lotus japonicus, Glycine max and Pisum sativum. The

9 establishment of these models has already boosted our understanding of important

10 processes such as the nitrogen-fixing symbiotic interaction. The high level of synteny

11 and collinearity existing between legumes makes possible the transfer of key knowledge

12 from model legumes to faba bean. Here we review the most recent knowledge gained

13 from model legumes on grain quality, resistance to biotic and abiotic stresses, nitrogen-

14 fixing symbiosis and how this knowledge can be employed for faba bean breeding.

16 Keywords: biotechnology, breeding, faba bean, model legumes, Vicia faba, Medicago

17 truncatula, Lotus japonicus

18

19

20 


\section{Introduction}

2 Grain legumes play a critical role in crop rotation. Thanks to the unique process of

3 biological fixation of atmospheric $\mathrm{N}_{2}$, grain legumes can meet two major challenges in

4 modern agriculture: (i) reduction of fossil energy use and green house gas emission

5 through decrease of nitrogen fertilizers, which contribute to both $\mathrm{CO}_{2}$ and $\mathrm{N}_{2} \mathrm{O}$

6 emissions; (ii) diversification of cropping systems to reduce the need for external inputs

7 such as pesticides, to improve nutrient and water use and to reduce losses of nutrients to

8 the environment. However, the inclusion of legumes in the cropping systems is still

9 rather low despite their beneficial functions towards sustainable and multifunctional

10 agroecosystems. To turn grain legumes into proper candidates for a sustainable

11 agriculture, they should be attractive both to producers and to users (human or animal 12 nutrition).

13 Faba bean is an excellent candidate crop to provide nitrogen input into temperate 14 agricultural systems. Significant genetic variation for symbiotic parameters exists with 15 numerous faba bean germplasm lines maintained, providing an excellent resource for 16 plant breeders (Duc et al., 2009, this issue). Priorities for faba bean breeding are the 17 development of resistant genotypes to biotic (Sillero et al., 2009, this issue) and abiotic 18 constrains such as over-wintering frost (Stoddard et al., 2009a, this issue) and drought 19 (Stoddard et al., 2009b, this issue), and free of anti-nutritional factors (Krepon et al., 202009 , this issue). Understanding the bottlenecks during symbiotic signalling and the 21 processes underlying nodule development and nitrogen assimilation are critical for the 22 improvement of current breeding programs. Critical traits to focus on faba bean 23 nodulation biology include high nodulation ability, tolerance to nitrate containing soils, 24 increased symbiotic mass to increase total nitrogen fixation ability, and interaction with 25 mycorrhizal fungi (cf. Meixner et al., 2007). Many of these traits have already been 
1 incorporated into modern cultivars, but several others, many of which are controlled

2 quantitatively by multiple genes, have been more difficult to manipulate.

3 Implementation of Marker-Assisted Selection (MAS) schemes offers plant breeders a

4 mean to improve selection efficiency, reducing the time and effort required to develop

5 new cultivars. Although Quantitative Trait Loci (QTL) mapping studies have been

6 performed for almost all grain legumes, in most cases no markers are readily available

7 for QTL selection and MAS yet. The limited saturation of the genomic regions bearing

8 putative QTLs makes difficult to identify the most tightly-linked markers and to

9 determine the accurate position of QTLs (Torres et al., 2009, this issue). Effectiveness

10 of MAS might soon increase with the adoption of the new improvements in marker

11 technology together with the integration of comparative mapping and functional

12 genomics. Traditional breeding efforts will be greatly enhanced through collaborative

13 approaches using functional, comparative and structural genomics. Development of

14 novel methods to introduce genes into grain legumes through plant transformation

15 methodology promises to give plant breeders the opportunity to overcome hybridization

16 barriers and other limitations related to those traits for which little or no natural

17 resistance has been identified in addition to provide means to study gene function and

18 genome organization. Molecular genetic and genomic analyses promise the transfer of

19 technology from model legumes to faba bean, despite a generation of neglect.

21 2. The Model Legumes

22 In the last three decades, the study of complex biological processes in plants has

23 been facilitated by the development of the model plant, Arabidopsis thaliana. This

24 model has already allowed various breakthroughs in our understanding of different

25 processes such as plant development (van Hengel et al., 2004; De Smet and Jurgens, 
1 2007) and plant response to biotic and abiotic stresses (Jones and Dangl, 2006; Swindell

2 et al., 2007; Ma et al., 2008). However, while the study and further development of $A$.

3 thaliana as a unique model improved greatly our understanding in some processes, its

4 limits also became apparent. Indeed, A. thaliana cannot be considered as the universal

5 model since, for instance, it is not the natural host of many pathogenic or symbiotic

6 bacteria and fungi (Handberg and Stougaard, 1992). Thus, several other species

7 including Oryza sativa, Medicago truncatula and Lotus japonicus have been more

8 recently proposed and developed as alternative models to address specific issues of a

9 more restricted group of plants.

$10 M$. truncatula and L. japonicus were initially developed as models to study the

11 nitrogen-fixing symbiosis, restricted to the Fabaceae, since each species responds

12 slightly differently to its rhizobial partner: L. japonicus forms determinate nodules

13 whereas M. truncatula forms indeterminate nodules (Handberg and Stougaard, 1992;

14 Rose, 2008). The fact that both are small self-fertile plants with a short growth cycle

15 and profuse flowering and seed production makes them ideal for classical and molecular

16 genetics since fast generation of a mapping population is easy to achieve. In addition,

17 M. truncatula and L. japonicus are diploid legume species with eight and six

18 chromosomes in their haploid phase respectively (Barker et al., 1990; Handberg and

19 Stougaard, 1992). Their genomes are relatively small estimated around 500 and $470 \mathrm{Mb}$

20 respectively (Sato et al., 2007), so only slightly higher than A. thaliana (125 Mb) and

21 significantly smaller than most legume species i.e. 4,000 $\mathrm{Mb}$ for pea or $13,000 \mathrm{Mb}$ for

22 faba bean (Barker et al., 1990; Handberg and Stougaard, 1992). Altogether, these

23 characteristics, along with the capabilities of these species to be transformed by

24 Agrobacterium tumefaciens or A. rhizogenes, have made of $M$. truncatula and $L$. 
1 japonicus valuable tools for the dissection of symbiotic interactions at the molecular

2 level and to address specific legume needs.

3 To facilitate the study of plant-microbe symbiotic interaction in legumes, different

4 tools for classical, molecular and reverse genetics, along with functional genomics were

5 developed in these two species. Several germplasm collections of both model species

6 are available that are useful to search for genetic polymorphism for particular traits.

7 Mining these collections allowed the development of several genetic maps, based on F2

8 populations, in both species using a wide array of genetic markers such as Cleaved

9 Amplified Polymorphic Sequence (CAPS), Amplified Fragment Length Polymorphism

10 (AFLP), Random Amplification of Polymorphic DNA (RAPD) and microsatellites that

11 are consolidated by the generation of Recombinant Inbred Lines (RILs) (Thoquet et al.,

12 2002; Choi et al., 2004a; Sandal et al., 2006; Wang et al., 2008). Among these maps, the

13 intra-specific maps in M. truncatula A17 x A20 (Ané et al., 2008) and in L. japonicus,

14 Gifu B129 x Mijakojima MG-20 (Wang et al., 2008), and the inter-specific map

15 between L. japonicus Gifu B129 and L. filicaulis (Sandal et al., 2006) have been used as

16 reference for map-based cloning and genome sequencing. The information obtained by

17 these genetic maps was complemented by the generation of cytogenetic maps based on

18 Fluorescence in-situ Hybridisation (FISH) on pachytene chromosomes, instrumental for

19 map-based cloning and comparative genomics (Kulikova et al., 2001; Pedrosa et al.,

20 2002). In addition, a genome sequencing initiative of gene-rich regions via the Bacterial

21 Artificial Chromosome (BAC)-by-BAC strategy and different Expressed Sequence Tag

22 (EST), sequencing programs have been initiated for M. truncatula and L. japonicus.

23 These programs have led to the creation of more than 200,000 and 100,000 ESTs,

24 available from public DNA database, for M. truncatula and L. japonicus, respectively, 
1 and the sequencing of nearly 190 and $315.1 \mathrm{Mb}$ of their respective genomes (Cannon et

2 al., 2006; Ané et al., 2008; Sato et al., 2008).

3 In parallel, transcriptomic and proteomic tools have also been developed in both

4 models as alternative approaches for the study of the symbiotic interaction and other

5 processes (Wienkoop and Saalbach, 2003; Colebatch et al., 2004; El Yahyaoui et al.,

6 2004; Kouchi et al., 2004; Hohnjec et al., 2005; Gallardo et al., 2007; Sanchez et al.,

7 2008). Several macro- and micro-array platforms have been developed in these species

8 initially to study the symbiotic interaction. Large-scale macro-array techniques allowed

9 the monitoring of 6,000 and 15,000 genes simultaneously in M. truncatula and $L$.

10 japonicus (El Yahyaoui et al., 2004; Kouchi et al., 2004). Targeted macro-array

11 platforms were also developed to study specific topic including a 92 defence-related

12 gene macro-array to study the $M$. truncatula-Colletotrichum trifolii interaction

13 (Torregrosa et al., 2004) or a 384 salt stress-related genes to study M. truncatula

14 response to salt stress (Merchan et al., 2007). Simultaneously, the first micro-array

15 platforms, developed at the University of Bielefeld (Germany) and the Max Planck

16 Institute of Molecular Plant Physiology, Golm (Germany) allowed the screening of

17 6,231 and 2,500 unique transcripts respectively (Colebatch et al., 2004; Küster et al.,

18 2004). With the progress of genome sequencing, the $M$. truncatula micro-array platform

19 was upgraded to allow the monitoring of 16,000 genes (Hohnjec et al., 2005) that have

20 also been completed with the entire Sinorhizobium meliloti genome to develop a dual

21 symbiotic chip (Barnett et al., 2004). In addition, Affymetrix chips with

22 bioinformatically optimized oligonucleotides are also commercially available for $M$.

23 truncatula and L. japonicus (http://www.affymetrix.com; Sanchez et al., 2008) and a

24 novel generation of $M$. truncatula gene chips with probe sets for 1,850 M. sativa

25 transcripts to facilitate transcriptomic analysis of closely related species will be soon 
1 available (Ané et al., 2008). In parallel to these large-scale hybridisation techniques, a

2 method for the simultaneous monitoring of more than 700 transcription factors by

3 quantitative Polymerase Chain Reaction (PCR) has been established at the Max Planck

4 Institute of Molecular Plant Physiology, Golm (Germany) (Kakar et al., 2008). All these

5 transcriptomic platforms allowed large improvements in our understanding of legume

6 symbiotic interactions and begin to be used for other purposes including the response to

7 salinity (Sanchez et al., 2008; Gruber et al., 2009), grain filling (Gallardo et al., 2007;

8 Verdier et al., 2008), or legume-pathogen interactions (Torregrosa et al., 2004; Curto et

9 al., 2007; Ameline-Torregrosa et al., 2008; Dita et al., 2009).

10 In turn, several proteomic approaches, based on different protein separation methods

11 and identification by mass spectrometry, have been developed and applied for these

12 model species. These original approaches targeted the establishment of reference

13 protein and peptide maps in M. truncatula (Watson et al., 2003) and the analysis of the

14 symbiotic compartment in both L. japonicus and M. truncatula (Wienkoop and

15 Saalbach, 2003; Valot et al., 2006; Larrainzar et al., 2007; van Noorden et al., 2007).

16 More recently, the range of application of proteomic approaches has been broadened to

17 include grain filling (Gallardo et al., 2003; Gallardo et al., 2007; Repetto et al., 2008)

18 and pathogen interactions (Colditz et al., 2005; Castillejo et al., 2009). Nowadays,

19 second and third generation proteomic tools such as Differential In-Gel Electrophoresis

20 (DIGE) and isobaric Tag for Relative and Absolute Quantitation (iTRAQ) are being

21 developed in $M$. truncatula along with approaches targeting the post-translational

22 modifications including nitrosylation and phosphorylation at large scale (M.A.

23 Castillejo, personal communication).

24 Apart from these genomic tools, many reverse genetic approaches were also

25 developed in these models. To this purpose, several collections of chemical or 
1 insertional mutants including T-DNA and transposon tagged lines have been created

2 (Thykjaer et al., 1995; Penmetsa and Cook, 2000; Webb et al., 2000; Kawaguchi et al.,

3 2002; Tadege et al., 2008). These collections have already been used to identify new

4 genes required for symbiosis but may also be screened for other interesting traits. The

5 improvement of PCR-based techniques for screening for mutation in gene of interest

6 allowed the development of novel approaches for efficient reverse genetic analysis.

7 Several of these novel approaches, have been or are being developed in M. truncatula

8 and L. japonicus including Targeted Induced Local Lesions in Genome (TILLING),

9 saturating Tnt1-insertion mutagenesis and fast-neutron mutagenesis. TILLING relies on

10 point mutagenesis with ethyl methyl sulfonate (EMS), and provides an allelic series

11 ranging from silent mutations to complete loss-of-function of the gene of interest. This

12 method was first developed for legume in L. japonicus (Perry et al., 2003) already

13 allowing the identification of novel symbiotic genes in this species (Heckmann et al.,

14 2006; Horst et al., 2007) and is now available in M. truncatula (the Grain Legumes

15 European Integrated Project (GLIP), http://www.eugrainlegumes.org/). In an attempt to

16 saturate the whole $M$. truncatula genome, a large collection of Tnt1-tagged $M$.

17 truncatula lines has been established along with the facilities to characterise the

18 transposon-flanking regions (Tadege et al., 2008). Fast-neutron mutagenesis detection

19 methods were also set-up for M. truncatula and L. japonicus, allowing the identification

20 of one non-nodulating mutant FNN5.2 in L. japonicus (GLIP,

21 http://www.eugrainlegumes.org/; Hoffmann et al., 2007). In addition to help identifying

22 new genes involved in plant biology, these methods can serve to identify the exact

23 function of these genes, which is a pre-requisite step before gene transfer into other

24 legume crops such as faba bean. Tnt1 mutagenesis and related transposon or T-DNA

25 tagging which insert within the gene and Fast neutron bombardment, which generates 
1 large deletions, are likely to produce gene knockouts, ideal to identify gene function but

2 the point mutants identified by TILLING may be more useful as a source of favourable

3 alleles for subsequent selection. Alternatively to these mutation-based methods, two

4 transformation-based methods, RNA interference (RNAi) and/or Virus-Induced Gene

$5 \quad$ Silencing (VIGS) were also established in these model legumes (Limpens et al., 2004;

6 Maeda et al., 2006).

7 Altogether all the resources developed in these two models make them ideal 8 candidates to study legume physiology and have already provided important

9 breakthroughs in our understanding of legume symbiosis. In addition, these two species

10 are also affected by most stresses limiting legume crop yield such as fungal and

11 bacterial diseases, nematodes, pests or salt stress so that the different resources

12 developed on these species provide a great advantage to improve our understanding and

13 the breeding for the specific needs of legume crops such as faba bean.

14 Alternatively of these two model legumes, several legume crops including soybean

15 and pea, have been extensively studied due to their economical importance. These two

16 crop species count on large collections of germplasms and chemical and insertional

17 mutants and are the subject of genomic sequencing initiatives. In addition, many

18 genomic tools have been and are being developed in these species including proteomic

19 and transcriptomic platforms and functional genomic approaches such as TILLING,

20 RNAi and VIGS silencing techniques (Constantin et al., 2004; Subramanian et al.,

21 2005; Zhang and Ghabrial, 2006; Cooper et al., 2008; Dalmais et al., 2008; Kaimoyo

22 and VanEtten, 2008). Thus these two legume crops can also serve as model to transfer

23 interesting traits to faba bean. 


\section{3. Synteny Between M. truncatula, L. japonicus and Grain Legumes}

2 Depending on the degree of their evolutionary relationship, different species

3 preserve similarities in the content, proximity (synteny) and linear order (collinearity) of

4 genes in their genomes. This suggestion derives from the idea that the relative location

5 of genes in a genome is an accident of history and that the decay of colinearity is simply

6 a function of chance and divergence time. Comparative mapping and genome analysis

7 investigate conservation and differences in gene content and order among different taxa.

8 Originally comparative analyses of genomes were performed based on genetic maps

9 developed with molecular markers, but the increasing availability of large-scale genome

10 sequences (www.plantgdb.org/prj/Genome browser.php) could make comparison more

11 direct and extensive. In the last three decades, multiple studies, using linkage maps,

12 revealed remarkable synteny predominantly within plant families (Paterson et al., 2000).

13 Conserved gene order between species from distinct plant families was also identified

14 within small-scale genomic regions (microsynteny) rather than simply among large

15 chromosome segments (Devos et al., 1999; Stracke et al., 2004; Kevei et al., 2005; Zhu

16 et al., 2005 and many others), although collinearity between large chromosomal blocks

17 of markers across species separated by wider taxonomic distances has also been

18 identified in a few cases (Lee et al., 2001; Wu et al., 2006).

19 Comparative genetic analysis among legumes species was launched by Vavilov's

20 studies (1922) on series of similar heritable variations in related Papilionoid species.

21 The first molecular proofs for the existence of macrosynteny between legumes were

22 given by the comparison of genetic maps of economically important grain legumes. The

23 comparison of the incomplete genetic maps of lentil (Lens culinaris; $2 n=14$ ) and

24 chickpea (Cicer arietinum; $2 \mathrm{n}=16$ ) with the pea linkage map revealed eight and five

25 large syntenic blocks respectively (Weeden et al., 1992; Simon and Muehlbauer, 1997; 
1 Ellis and Poyser, 2002). Comparison between pea and M. sativa, also revealed a

2 substantial conservation in the gene order in these species. This comparison allows to

3 identify the genetic rearrangements that occurred and account for their chromosome

4 number difference (8 for alfalfa and 7 for pea; Kaló et al., 2004), which also indicated

5 that the 10 -fold difference in their genome size is not the result of large scale pea

6 genome multiplication. Completing the $M$. truncatula genetic map with $M$. sativa gene-

7 based genetic markers (Kaló et al., 2000) identified the homologous linkage groups and

8 showed an almost complete colinearity between these two related species except for the

9 rDNA chromosomal localization (Choi et al., 2004a). For the Phaseolid legumes, a high

10 level of collinearity and synteny was detected as shown between the genome of several

11 Vigna species (Menancio-hautea et al., 1993; Kaga et al., 2000) and between V. radiata

12 (mungbean) and the phaseolid legumes Dolichos lablab (Humphry et al., 2002) and

13 common bean (Boutin et al., 1995). Comparison of genetic maps between soybean and

14 common bean revealed only short conserved linkage blocks in common bean that often

15 corresponded to nearly entire linkage groups or large contiguous blocks in soybean

16 (Boutin et al., 1995; Lee et al., 2001).

17 The genomic resources developed for M. truncatula, L. japonicus, soybean and 18 common bean boosted comparative genomic analyses between model legumes and 19 legume crops by allowing more comprehensive macrosynteny analyses such as those 20 reported by Choi et al. (2004b) and Zhu et al. (2005). Cross-species gene specific 21 markers were used to identify homologous genome segments among eight legume 22 species (M. truncatula, alfalfa, L. japonicus, pea, chickpea, soybean, mungbean and 23 common bean). Using the $M$. truncatula genetic map as a reference genome, the eight 24 legume genomes were aligned and a simplified consensus map was created. The degree 25 of collinearity between legumes reflected their phylogenetic relationship. The large 
1 amount of genomic sequences generated between the two model legumes $M$. truncatula

2 and L. japonicus allows a more comprehensive in-clade comparison showing several

3 macrosyntenic regions and significant microsyntenic regions conserving many genes in

4 the same order and orientation (Fig. 1; Choi et al., 2004b; Cannon et al., 2006). The

5 comparison of the microstructure of the MtDMI2(NORK)/LjSYMRK region also

6 revealed a nearly complete conservation in gene content and order between the two

7 species within a $276 \mathrm{~kb}$ long M. truncatula chromosomal segment (Kevei et al., 2005;

8 Zhu et al., 2005). The comparative mapping between $M$. truncatula and soybean

9 identified eleven colinear blocks with a high degree of microsynteny (Choi et al.,

10 2004b; Mudge et al., 2005). Similarly, segments of eight linkage groups of common

11 bean $(2 n=22)$ exhibited conservation with $M$. truncatula linkage groups (Choi et al., 12 2004a; 2004b).

13 A similar approach - generating intron-targeted gene-based anchor markers for

14 legume species and using $M$. truncatula as a reference genome for comparative 15 mapping - was applied in the comparative mapping program of GLIP 16 (http://www.eugrainlegumes.org/) to analyse macrosyntenic relationship between pea, 17 chickpea, faba bean, common bean, lupin and lentil. The alignment of the legume 18 genetic maps is currently underway and preliminary data show that high level of 19 macrosynteny exists between the genomes of $M$. truncatula, lentil (Phan et al., 2006), 20 faba bean and chickpea (Gutierrez et al., 2008b; P. Winter personal communication).

21 These analyses also indicated a complex syntenic pattern between $M$. truncatula and 22 lupin for which individual $M$. truncatula chromosomes were syntenic to at least two 23 lupin linkage groups accounting to the higher lupin chromosome number (Nelson et al., 24 2006; Phan et al., 2006; Phan et al., 2007). In parallel, syntenic analysis between $M$. 
1 truncatula, L. japonicus and peanut (Arachis hypogea), a more distant grain legume,

2 revealed significant macrosynteny between these species (Hougaard et al., 2008).

3 These recent comparative genomic studies have mainly used $M$. truncatula as a

4 reference genome and revealed that colinearity exits between legume species to

5 different extents depending on their phylogenetic distance. In order to support

6 comparative legume biology the Legume Information System (LIS) was developed

7 (Gonzales et al., 2005) few years ago, which integrates genetic and physical map data

8 and enables macrosynteny analyses to be carried out between legume species in silico.

9 Both M. truncatula and faba bean are cool season legumes falling into two separate

10 tribes; faba bean $(2 n=12)$ belongs to the Viciae and M. truncatula is a species in

11 Trifoliae tribe (Zhu et al., 2005). The genome size of faba bean is about 25-fold larger

12 than the genome of M. truncatula, which restrained the development of faba bean

13 genomics. A composite genetic map of $V$. faba has been constructed (Román et al.,

14 2004) and, in the frame of GLIP, intron-targeted gene-based markers have been

15 developed and tested for faba bean. The comparative mapping between faba bean and

16 M. truncatula is in progress (Gutierrez et al., 2008a). Based on the phylogenetic

17 distance between the two species, large scale genome conservation is expected and the

18 identification of chromosome rearrangements responsible for different chromosome

19 number is likely, as it has been detected between $M$. truncatula and pea (Choi et al.,

20 2004b; Kaló et al., 2004). The expected high level of conservation in gene order

21 between faba bean and $M$. truncatula implies that $M$. truncatula genomic tools will

22 facilitate breeding and research of faba bean. 
A major aim for any crop breeding program is the development of good quality lines

2 with an adequate resistance/tolerance to yield-reducing stresses. The use of model

3 legumes for comparative functional genomics may bring some new perspectives and

4 enhance faba bean breeding efforts. In this way, identification of QTLs and/or candidate

5 genes involved in stress tolerance and/or quality may be used to produce transgenic

6 lines and/or these traits can be applied to breeding programs (e.g., MAS).

7 Little is known about the functional correspondence of model legume genes and

8 their putative faba bean orthologues. Notwithstanding the lack of information,

9 predictions can be made based on the sequence similarities between the relatively few

10 M. truncatula and faba bean gene pairs that are available and the high conservation and

11 synteny existing between legume genomes. Whereas for highly conserved genes,

12 favourable mutations observed in model legumes are likely to correspond to favourable

13 alleles in faba bean, for less conserved genes (i.e. many transcription factors), the

14 relation is less reliable. Possible complications include 1) differences in gene copy

15 number, 2) differences in transcript or protein abundance, 3) differences in specific

16 activity. Therefore, the information obtained in model legumes can be used as a guide to

17 narrow down candidate genes, but proof can only come from functional studies, 18 preferably in the homologous system.

19 Once a series of candidate genes to improve a particular trait has been identified 20 in one of the model legumes, a number of options are possible for exploiting this 21 information in legume crops and particularly in faba bean breeding. The involved steps 22 are: 1) confirmation of candidate gene function either directly in faba bean or indirectly 23 in any of the model legumes, 2) identification of favourable alleles for selection, 3)

24 variety improvement by MAS or by transformation of an elite line. 
Several approaches have been developed to confirm candidate gene function at

2 the biochemical and physiological level. Originally, functional analysis of proteins was

3 performed through two main techniques, protein over-expression and monitoring of

4 promoter activity. Over-expression of a candidate gene is obtained by transferring the

5 coding region of the gene under control of a strong promoter such as the CaMV $35 S$ into

6 the plant and function is assigned by scoring the phenotype of the resulting transformed

7 line (Shimoda et al., 2008; Vernié et al., 2008). Promoter activity analysis is performed

8 by linking the promoter sequence to reporter gene such as the beta-glucuronidase (GUS)

9 or the green fluorescent portein (GFP) to allow analysis of tissue-specific expression

10 (Hayashi et al., 2008). Both procedures require gene transfer that is difficult in large

11 seeded legumes. This limitation can often be short-cut by hairy root transformation that

12 is easier to achieve but only allows analysis of gene constructs in root tissue. Albeit

13 with low efficiency, protocols for both A. tumefaciens and A. rhizogenes transformation

14 have been established for faba bean and can be used for gene functional analysis in this

15 species (Böttinger et al., 2001; Vieweg et al., 2004). Alternatively, the functional

16 analysis could be performed in the model legumes M. truncatula, L. japonicus or

17 soybean for which the transformation protocols are more efficient and rapid (Lombari et

18 al., 2003; Crane et al., 2006; Kereszt et al., 2007; Rech et al., 2008).

19 In these model legumes, gene function can also be removed by modern

20 molecular genetic techniques including RNAi (Wesley et al., 2001), VIGS (e.g.

21 Kachroo et al., 2008) and even TILLING (Colbert et al., 2001). The TILLING approach

22 is also available for G. $\max$ (Cooper et al., 2008) and P. sativum (Dalmais et al., 2008)

23 but not yet for faba bean, the difficulty being generation and maintenance of a large

24 perfectly homozygous population for mutagenesis. 
Once the function of a candidate gene has been validated, identification of

2 favourable alleles has to be performed. Defining patterns of synteny and collinearity

3 between species by comparative genomic studies (cf. section 3 ) helps the identification

4 of orthologous genes in genetically recalcitrant species as compared to model systems.

5 Once a gene behind a given phenotype has been identified by a map-based cloning

6 approach and validated, the orthologous gene in the other species can be isolated based

7 on similar map position. There are several examples for this fruitful approach among the

8 legume species where genes involved in symbiotic interactions have been identified

9 (e.g. pea mutants sym19 - DMI2/NORK, sym2 - LYK3, sym7 - NSP2; Endre et al., 2002;

10 Limpens et al., 2003; Kaló et al., 2005). The syntenic map position of the dwarf

11 phenotype in diploid alfalfa (Msdwf1) and pea (le) and the genomic resources in $M$.

12 truncatula enabled the identification of a gene encoding a gibberellin 3- $\beta$-hydroxylase

13 (GA3ox) required for normal growth habit in diploid alfalfa (Dalmadi et al., 2008).

14 These examples clearly demonstrate the two-way utility and application of molecular

15 markers and the identified orthologous regions between the genomes of reference and

16 crop legumes. The tools developed in model species can facilitate the identification of

17 agronomically important genes (QTLs, genes involved in nutrient quality and quantity,

18 biotic and abiotic stresses, etc.) and marker-assisted breeding programs in target

19 organisms while the accumulated biological knowledge in crop species can contribute

20 the understanding of biological processes. Alternatively, selection of favourable alleles

21 of the gene of interest can be found using the EcoTILLING approach that allows the

22 detection of allelic variants of a candidate gene in natural populations for their

23 subsequent phenotyping for the trait in question. Finally, the favourable allele can be

24 transferred to elite faba bean cultivars by MAS or genetic transformation. 


\section{5. Application of Model Legumes to Faba Bean Improvement}

$2 \quad$ 5.1. Breeding for quality

\subsubsection{Model legumes and quality traits}

M. truncatula seed biology is essentially very similar to that of the major temperate crop legumes, pea and faba bean, but differs in that the major carbon reserves are lipids, rather than starch, which is present only in trace amounts in the mature seed. The $M$. truncatula seed also contains about $10 \%$ of endosperm material at maturity, unlike pea or faba bean in which this layer is reabsorbed during development. As M. truncatula was not bred for grain consumption, its seeds are also relatively small with a relatively high proportion of cell wall material and a low harvest index. Proteins represent the major class of storage compounds in M. truncatula seeds, followed by lipids, with only trace quantities of starch (Duc, 2004; Djemel et al., 2005). Whereas proteins and oils are coordinately synthesized during seed filling, the non-starch carbohydrate fraction (mainly trachyose) accumulates only at the end of seed maturation, when seeds are acquiring desiccation tolerance. Fatty acid and sugar compositions are similar to those of pea and other grain legumes. Thus, with certain caveats, the M. truncatula seed is a good model for identifying genes important in regulating seed composition in grain legumes.

\subsubsection{Identification of grain quality characters}

The availability of a comprehensive EST database has allowed a large-scale identification of genes putatively encoding $M$. truncatula seed proteins that have been subsequently confirmed by seed protein separation and Matrix-Assisted Laser Desorption/Ionization - Time-of-Flight (MALDI-TOF) analysis, some of which are candidate genes for quality traits (Watson et al., 2003; Gallardo et al., 2003). The major 
1 M. truncatula storage proteins are the $7 \mathrm{~S}$ (vicilin and convicilin-type) and $11 \mathrm{~S}$

2 (legumin-type) globulins, with similar amino acid compositions to those of other grain

3 legumes, notably being poor in sulphur-containing amino acids (Gallardo et al., 2003).

4 The storage proteins accumulate sequentially during seed filling, the vicilins at 14 days

5 after pollination (DAP) followed by the legumins (16 DAP) with the convicilins

6 accumulating last (18 DAP).

7 Among the proteins identified at different developmental stages, several 8 enzymes and other proteins playing key roles in the seed were detected. For example,

9 cell division-associated proteins were expressed during the differentiation phase 10 preceding seed filling. Storage protein accumulation was accompanied by the 11 expression of putative chaperonins and protein disulphide isomerases. During this 12 phase, two PV100-like polypeptides also accumulate (Yamada et al., 1999) giving rise 13 to a trypsin inhibitor and a cytotoxin-related peptide upon processing, which are 14 important targets for breeding as their elimination could improve nutritional quality of 15 legume seeds.

16 Starch accumulates only transiently in $M$. truncatula seeds, in contrast to the 17 starch-rich pulse pea and faba bean, but similarly to the situation in soybean, starch 18 remobilisation is the contributing carbon source for oil biosynthesis (Duc, 2004).

19 Certain starch-remobilisation enzymes (starch synthase, sucrose synthase and triose 20 phosphate isomerase) were transiently expressed 16-24 DAP, concomitantly with 21 proteins involved in photosynthesis, supporting the hypothesis that photosynthesis in the 22 embryo provides energy for lipid biosynthesis, which may also recycle fixed $\mathrm{CO}_{2}$ 23 (Gallardo et al., 2003).

24 Seed development involves the interplay of several tissues; the developing 25 embryo is surrounded by the endosperm, and the two organs are embedded in the 
1 maternal integument. The role played by the embryo-surrounding tissues in legume seed

2 reserve accumulation has been investigated genetically for pea and soybean (Lemontey

3 et al., 2000), indicating significant maternal effect early in seed filling. To study these

4 interactions in more detail and get access to the genes involved, gene expression in

5 these tissues has been analysed at the proteome and transcriptome levels (Gallardo et

6 al., 2007). A general observation is that the pattern of proteins and transcripts expressed

7 in the embryo, endosperm and integument is very specific for each cell type, with little

8 overlap. One of the major findings was an extensive compartmentalization of amino

9 acid metabolism between seed tissue components that may favour storage product

10 accumulation. Of particular interest is the compartmentalization of enzymes of sulphur

11 amino acid biosynthesis, observed for both methionine and cysteine, as these are

12 limiting in grain legumes.

13 The dependence of the embryo's nutrition on the maternal tissue was also

14 demonstrated directly by an in vitro culture experiment in which embryo development

15 on nitrogen nutrient-free medium with and without the surrounding tissue was

16 compared (Gallardo et al., 2006). Embryos grown without nitrogen source aborted,

17 whereas embryos grown in presence of the surrounding endosperm and integument

18 developed normally and accumulated reserve proteins, presumably due to nitrogen

19 remobilisation from maternal tissues. This remobilisation of a temporary nitrogen store

20 requires proteolysis, and candidate proteases with appropriate expression kinetics have

21 been identified in endosperm and seed coat tissues (Gallardo et al., 2007).

22 Seed developmental programme is under tight transcriptional control, and there

23 is evidence from other plant systems that an important class of loci regulating seed

24 composition corresponds to transcription factors (Le et al., 2007). To identify

25 transcription factors (TFs) expressed in developing $M$. truncatula seeds, expression of 
1 more than 700 TF sequences was monitored by quantitative real-time PCR throughout

2 seed development (Verdier et al., 2008). By clustering the data of TF expression with

3 storage protein expression profiles previously obtained, candidate factors potentially

4 controlling the major storage protein groups were identified. In parallel, a biochemical

5 approach analysing the nuclear proteome led to the identification of several putative

6 regulatory proteins (Repetto et al., 2008), the functions of which remain to be

7 determined by reverse genetics. Identified genes and proteins from all these studies may

8 serve as quality markers potentially transferable to crop legumes for breeding once their

9 involvement in seed quality is determined and polymorphism for these traits are found.

10 A survey of natural variations in seed protein complements carried out on 50

11 diverse Medicago truncatula ecotypes or cultivars indicated a high degree of

12 polymorphism in protein composition and a large variation in protein content $(33-46 \%)$

13 (Le Signor et al., 2005). Clustering of genotypes according to similarity in one-

14 dimensional protein profiles allowed structuring into classes that corresponded to 4

15 species groups within the $M$. truncatula species complex. This classification has

16 allowed the selection of RIL parents for maximizing variation in protein content and

17 type in the populations to be examined, and mapping of QTLs is in progress. In a new

18 project, expressional gene candidates, selected from the cited studies, are being mapped

19 directly on the genetical-physical $M$. truncatula map for comparison with the positions

20 of mapped traits. So far, around $50 \%$ of the gene candidates have been mapped, giving a

21 total of around 750 loci, including transcription factors, nutrient transporters and other

22 seed-specific enzymes of metabolism (A. Bordat, personal communication). A survey of

23 QTLs for traits affecting vegetative plant development and seed yield and content in pea

24 (Burstin et al., 2007) revealed the importance of genes determining plant architecture in

25 controlling seed yield and protein content. It would appear likely that the homologous 
1 loci in faba bean have the same properties, and therefore these should form part of

2 selection schemes.

Apart from selection for seed size and seed number per pod, quality breeding in

4 faba bean has to date concentrated on the reduction/elimination of the anti-nutritional

5 factors condensed tannins, vicine and convicine, responsible for favism, a severe

6 digestive disorder in susceptible individuals, which reduce nutritional value of faba

7 bean (Gutierrez et al., 2006; Gutierrez et al., 2007; Gutierrez et al., 2008a). CAP

8 markers have been obtained for the convicine locus $v-c$, and SCAR markers for the

9 tannin loci zt-1 and zt-2 for use in introgression of favourable alleles in breeding

10 selection. Linked molecular markers such as these may be subject to recombination with

11 the trait of interest. With the sequence data available from M. truncatula, there should

12 be the possibility of identifying genes encoding the responsible enzymes, and thus of

13 obtaining non-recombining and hence more reliable SNP markers within the gene itself.

14 The development of inbred lines, perhaps based on the closed flower mutation (Poulsen,

15 1977), would facilitate genetic analyses.

$17 \quad 5.2$ Breeding for resistance to biotic stresses

Grain legume and in particular faba bean are challenged by many pathogens and

19 pest including bacterial, virus and fungal diseases as well as infection by nematodes and

20 some parasitic plants which strongly affect crop yield worldwide (see Pérez-de-Luque et 21 al., 2009, this issue; Sillero et al., 2009, this issue; Stoddard et al., 2009c, this issue).

22 Genetic resistance is considered the most desirable control method since it is more cost 23 effective and environment-friendly than the use of chemicals. Thus, many resistance 24 sources (Sillero et al., 2009, this issue) and their associated QTLs have been found in 25 different grain legumes including faba bean (Torres et al., 2009, this issue). However, 
1 the long genetic distance existing in most cases between the identified genetic markers

2 and the resistance QTLs, the common lack of codominant markers and the general lack

3 of knowledge on resistance mechanisms in legumes limit greatly the use of genetic

4 markers to confer resistance to grain legumes. The model legumes $M$. truncatula and $L$.

5 japonicus are affected by many of the pathogens and pest limiting faba bean yield.

6 Thus, they offer a great opportunity to improve the knowledge in resistance mechanisms

7 against faba bean pathogens and identify effective resistance genes against them.

Fungal and oomycete pathogens are the most diverse group of pathogens and

9 cause the most dramatic damages on legume yield worldwide. Annual Medicago and $M$.

10 truncatula in particular are strongly affected by a wide range of foliar and soil-borne

11 necrotrophic fungi which makes of $M$. truncatula a promising model to study the plant-

12 necrotrophic fungi interaction (reviewed in Tivoli et al., 2006). Several studies revealed

13 that M. truncatula is a potential host not only of necrotrophic fungi but also of several

14 biotrophic fungal and oomycete pathogens including Aphanomyces euteiches (Moussart

15 et al., 2007), Colletotrichum trifolii (O'Neill and Bauchan, 2000), Erysiphe pisi (Prats et

16 al., 2007), Fusarium spp. (Barbetti and Allen, 2005), Leptosphaerulina trifolii (Barbetti,

17 2007), Mycosphaerella pinodes (Moussart et al., 2007), Phoma medicaginis (O'Neill et

18 al., 2003; Ellwood et al., 2006; Barbetti, 2007), Peronospora trifoliorum (Yaege and

19 Stuteville, 2000), Uromyces striatus (Rubiales and Moral, 2004). In most cases,

20 screening of germplasm collections of $M$. truncatula allowed identification of a wide

21 range of differential responses to the pathogen from highly susceptible to resistant

22 (Moussart et al., 2007; Prats et al., 2007). This serves as bases for the characterisation of

23 underlying resistance mechanisms at the cellular and molecular levels as well as for the

24 identification of defence genes and QTLs responsible for resistance. 
2 controlled by single major genes, named rnpm1 and RCT1 respectively. These major 3 genes localised at the top of the linkage group 4 in a region containing a cluster of 4 several nucleotide binding site (NBS) - leucine rich repeat (LRR) proteins that are often 5 plant resistance (R) genes (Torregrosa et al., 2004; Yang et al., 2007; Kamphuis et al., 6 2008). Interestingly, the RCT1 gene of M. truncatula has been successfully transferred 7 to alfalfa to confer anthracnose resistance (Yang et al., 2008). Resistance to $A$. 8 euteiches, $M$. pinodes, $U$. striatus, $P$. trifoliorum or E. pisi appears to be controlled by 9 different defence mechanisms. For instance, screening of an USDA collection of $M$. 10 truncatula germplasms for E. pisi resistance indicated that resistance to powdery 11 mildew was controlled by papilla formation, by early hypersensitive response and also 12 by post-haustorial mechanisms (Prats et al., 2007). Mapping of the QTLs controlling 13 resistance to these fungal pathogens in $M$. truncatula is now underway (D. Rubiales, 14 personal communication). In parallel, the transcriptomic and proteomic approaches developed for this 16 model legume are being used to understand the molecular components and to identify 17 candidate genes involved in $M$. truncatula defence against these fungal pathogens. For 18 instance, a Substractive Suppression Hybridisation (SSH) library indicated that 19 Pathogen-Related (PR)10 proteins and proteins associated with abscisic acid signalling 20 play important roles in the $M$. truncatula resistance against $A$. euteiches (Nyamsuren et 21 al., 2003). The crucial role of PR10 in A. euteiches resistance was confirmed by 22 comparative proteomic and gene silencing approaches, which indicated that PR10 23 silencing led to increased resistance by antagonist induction of other PR genes (Colditz 24 et al., 2004; Colditz et al., 2007). Comparison of the proteomic profile of several M. 25 truncatula lines with varying levels of resistance also identified other proteins 
1 potentially involved in A. euteiches resistance such as proteasome alpha subunits

2 (Colditz et al., 2005). Comparison of expression profiles of 92 defence-related genes by

3 macroarray between a resistant and a susceptible line of $M$. truncatula at key steps of $C$.

4 trifolii infection also highlighted the important role of PR proteins and in particular

5 PR10 in resistance. As expected, this analysis indicated that a large proportion of genes

6 present on the macroarray membrane were upregulated in the resistant $M$. truncatula

7 line while these genes were mainly downregulated in the susceptible line. Microarray

8 analysis of several $M$. truncatula genotypes with different defence mechanisms against

9 E. pisi allowed the identification of a set of genes involved in these defence mechanisms

10 (Curto et al., 2007; Foster-Hartnett et al., 2007). Post-genomic approaches are also

11 being applied to tackle other fungal diseases such as M. pinodes (Fondevilla et al., 12 2008) and U. striatus (Madrid et al., 2008).

13 Legumes are also affected by bacterial pathogens. In particular, M. truncatula 14 can be infected by the causing agent of the bacterial wilt disease, Ralstonia 15 solanacearum, which also infects a large number of crops including tomato, potato and 16 cultivated legumes such as faba bean. A recent study showed that one M. truncatula 17 line, F83005.5, susceptible to C. trifoliorum and P. medicaginis, was resistant to most 18 R. solanacearum isolates (Vailleau et al., 2007). A major QTL was mapped on 19 chromosome 5 and two minor ones on chromosome 3 and 7 that may be helpful for 20 MAS (Vailleau et al., 2007).

21 Nematodes are also an important cause of yield losses in legumes. Interestingly,

22 M. truncatula and L. japonicus have been shown susceptible to most nematodes 23 affecting legumes. For instance, $M$. truncatula can be colonised by the stem nematode

24 Ditylenchus dipsaci, causing disease in many legumes such as alfalfa, pea and faba bean 25 (Plowright et al., 2002; Moussart et al., 2007). By screening a M. truncatula germplasm 
1 collection, Moussart et al. (2007) identified several resistant and susceptible $M$.

2 truncatula lines that will surely allow a better understanding of stem nematode-legume

3 interaction. L. japonicus and M. truncatula are also infected by different root-knot and

4 cyst nematodes belonging to the Meloidogyne and Heterodera genera. Interestingly,

5 Weerasinghe et al. (2005) showed, in L. japonicus, that root-knot nematode and

6 rhizobium interactions may share common pathways. Indeed they found that $L$.

7 japonicus mutants deficient for nitrogen-fixing symbiosis establishment were more

8 resistant to Meloidogyne incognita than the wild type while a hypernodulating mutant

9 was infected to a higher extent by the nematode (Weerasinghe et al., 2005). On the other

10 hand, screening of $L$. japonicus ecotypes revealed differential infection responses

11 according to the ecotype ranging from susceptible to resistant to this nematode. Such

12 genetic diversity is being used to map and identify genes and/or QTLs involved in root-

13 knot nematode resistance (Poch et al., 2007).

14 Although less studied, legumes are also under the thread of viruses. Despite the

15 damage they cause, very little is known about virus resistance mechanisms and nearly

16 no studies have aimed at the characterisation of virus resistance in the two model

17 legumes $M$. truncatula and L. japonicus. The only report published to date indicated

18 that L. japonicus could be infected by Arabis mosaic virus and Tobacco ringspot virus

19 while it was resistant to most legume infecting viruses (Schumpp et al., 2007). Due to

20 their economic importance, virus diseases have been more studied in soybean, which

21 thanks to its relatively small genome and the development of genomic tools begins to be

22 considered as the third model legume (Maroof et al., 2008b). In this species, several

23 resistance genes to the soybean mosaic virus have been identified and pyramidized in a

24 single cultivar (Maroof et al., 2008a). In parallel, Babu et al. (2008) found that during

25 the susceptible interaction, the defence reaction was only activated at the latest stages of 
1 the interaction, which may be critical for the systemic infection of the virus.

2 Independently, several transgenic approaches have been undertaken leading to increased

3 resistance against several viruses including the soybean mosaic virus (Furutani et al.,

4 2007) and the soybean dwarf virus (Tougou et al., 2007).

In semi-arid regions worldwide, including Southern and Eastern Europe, North

6 and East Africa and the Middle East, parasitic plants of the Orobanche spp. including

7 O. crenata, O. aegyptiaca and O. foetida drastically decrease legume yield. $M$.

8 truncatula has been recently proposed as a model to study the interaction Orobanche

9 spp. - legumes (Rodriguez-Conde et al., 2004; Lozano-Baena et al., 2007; Fernández-

10 Aparicio et al., 2008). L. japonicus can be infected by O. aegyptiaca, but shows

11 incompatible interaction against O. minor, Striga hermonthica or S. gesnerioides (Kubo

12 et al., 2009). Even when L. japonicus is not infected by O. minor, its root exudates have

13 strong stimulatory activity of $O$. minor, as well as of O. crenata, O. densiflora, O.

14 aegyptiaca and O. ramosa seeds (Fernández-Aparicio et al., 2009).

15 To improve our understanding of the M. truncatula-O. crenata interaction, a

16 SSH library has been created, allowing the identification of around 300 candidate genes

17 for $O$. crenata defence (Dié et al., 2007). In addition, a microarray analysis of the $M$.

18 truncatula genes regulated in response to $O$. crenata was recently performed on the

19 M16kOLI1 microarray platform (M.A. Dita, unpublished). A comparison of two-

20 dimension proteomic profile of two M. truncatula genotypes varying in their level of

21 resistance against $O$. crenata was also performed (Castillejo et al., 2008). Preliminary

22 analysis of the comparison of the transcriptome of two $M$. truncatula genotypes with

23 different resistance mechanisms indicated significant changes in the steady-state level of

24 many transcripts belonging to several functional categories, including pathogen-induced

25 genes, such as PR genes, hormone-associated genes and transcription factors. These 
1 analyses also revealed the activation of both the salicylic acid and jasmonate defence-

2 pathways (M.A. Dita, unpublished). These preliminary results support the previously

3 established results and should prove useful to identify potential candidate genes for crop

4 improvement. These candidate genes should be validated through functional analysis.

5 Validated candidates may then be used for genetic improvement of crop either directly

6 through genetic transformation or indirectly by MAS.

7

\subsection{Breeding for resistance to abiotic stresses}

Global climate change predictions suggest new scenarios with larger arid areas and extreme climatologic events. Thus, it is essential to understand how plants respond to

11 different abiotic stresses in order to improve crop performance. This difficult task can only be achieved by integrating conventional breeding and biotechnological approaches

13 (Chaves et al., 2003). However, most legume crops are not easily amenable for molecular and genetic studies. To circumvent this limitation knowledge gained on the two model legumes M. truncatula and L. japonicus may be further used to understand 16 the responses to abiotic stresses in other legumes such as faba bean.

Among the numerous environmental constrains affecting crop yield, drought is considered the most limiting factor with important economic consequences (Jones,

19 2004). M. truncatula is quite a drought-tolerant plant species compared to grain 20 legumes such as pea (González et al., 1998; Gálvez et al., 2005) or soybean (González 21 et al., 1995). Based on physiological and biochemical studies, M. truncatula responses 22 to drought appear to be similar to those described in alfalfa (Rubio et al., 2002; Naya et 23 al., 2007). The relative drought tolerance of $M$. truncatula has been shown in a recent 24 study, where moderate water deficit had only a slight significant effect on plant 25 biomass, presenting some differences among cultivars/ecotypes (Limami et al., 2006). 
1 Nunes et al. (2008) have further corroborated this relative tolerance, showing that under

2 mild drought conditions $M$. truncatula plants were able to avoid leaf dehydration and

3 under severe drought stress plants maintained significantly high net $\mathrm{CO}_{2}$ fixation rates.

4 Particular emphasis has been laid on the regulation of symbiotic nitrogen fixation

5 (NF) under drought stress in nodulated legumes. In contrast to earlier studies in soybean

6 (González et al., 1995) and pea (González et al., 1998; Gálvez et al., 2005), analysis in

7 M. truncatula suggests that the drought-induced downregulation of sucrose synthase is

8 not the main responsible for the inhibition of NF (R. Ladrera, E.M. González, C.

9 Arrese-Igor, unpublished), similarly to observations in M. sativa (Naya et al., 2007).

10 Additionally, the response to drought at the nodule level has been recently analysed

11 under a proteomic perspective (Larrainzar et al., 2007), where new marker enzymes

12 such as plant methionine synthase and bacteroid serine hydroxymethyltransferase were

13 identified. Regarding L. japonicus, Díaz et al. (2005) reported an accumulation of

14 proline and oxidative damage in leaves upon different water deprivation treatments.

15 Although the first studies analysing the response of this legume to water deficit have

16 started to emerge, most of the published work so far is based on other Lotus spp.

17 (Olsson et al., 1996; Carter et al., 1997; Borsani et al., 1999; 2001; Banon et al., 2004).

18 Plant responses to salt stress have been extensively analysed (reviewed in

19 Hasegawa et al., 2000; Yamaguchi and Blumwald, 2005), with an especial emphasis on

20 the role played by different osmolytes in homeostasis maintenance. Some compounds

21 such as proline-betaine, trehalose or trigonelline, a pyridine betaine, have been reported

22 to play a role in the response to salt stress of different legumes (Tramontano and Jouve,

23 1997; Trinchant et al., 2004; López et al., 2008). Furthermore, proline accumulation has

24 been shown to enhance NF during salt stress in M. truncatula (Armengaud et al., 2004;

25 Verdoy et al., 2006). In a recent functional analysis, Sanchez et al. (2008) reported a 
1 general increase in the steady-state level of many amino acids, sugars and polyols, with

2 a concurrent decrease in most organic acids in response to gradual salt stress in $L$.

3 japonicus leaves. On the other hand, molecular approaches have been applied to

4 examine the response of $M$. truncatula and $M$. sativa under salinity leading to the

5 identification of several transcription factors related to the plant root response to salt

6 stress (Merchan et al., 2003; de Lorenzo et al., 2007; Merchan et al., 2007).

7 The effect of low temperatures on plants has also received considerable attention.

8 Unfortunately, little is know about the response of legumes to this type of stress, as

9 most of the published reports are based on model plants such as A. thaliana. Plant cold

10 acclimation is a complex process, which involves the specific expression of cold-

11 induced genes to stabilize membranes against freeze-induced injury. This group

12 includes genes encoding late embryogenesis-abundant proteins, enzymes required for

13 osmolyte biosynthesis, antifreeze proteins, chaperones and detoxification enzymes,

14 under the control of several cold-induced transcription factors (Thomashow, 1999;

15 Heino and Palva, 2003). Based on the information available, it appears that $M$.

16 truncatula exhibit a poor freezing tolerance, when compared to other annual legumes

17 (Brandsaeter et al., 2002). This might be due to an ineffective cold acclimation process

18 and low starch reserves in this species (Hekneby et al., 2006). Interestingly, the $M$.

19 truncatula ZFP1 gene, encoding a root-enhanced zinc finger protein with high similarity

20 to a soybean cold-inducible protein, is not regulated by low temperature, suggesting a

21 different physiological function of this protein in both legume species $\mathrm{Xu}$ and $\mathrm{Ma}$,

22 2004). Some promising results for low temperature legume breeding have been obtained

23 by transgenic expression of an iron-superoxide dismutase in alfalfa, resulting in an

24 enhanced winter survival (McKersie et al., 1993; 2000) 
1 Flooding is another environmental stress that negatively influences germination,

2 seedling establishment and plant development, as it causes a limitation in the flux of

3 oxygen to support plant respiration (Bailey-Serres and Voesenek, 2008). Besides the

4 activation of alcohol and lactic fermentative pathways, flooding stress on M. truncatula

5 seedlings induces activity of mitochondrial alanine aminotransferase and glutamate

6 dehydrogenase which may contribute to the maintenance of the redox balance during

7 fermentative growth (Ricoult et al., 2005; 2006). The involvement of non-symbiotic

8 hemoglobins in flooding stress adaptation has been shown in L. japonicus (Shimoda et

9 al., 2005), and soybean (Lee et al., 2004), whereas promoter analysis carried out in faba

10 bean suggested that symbiotic leghemoglobins were not induced upon hypoxia (Vieweg

11 et al., 2004).

12 In the context of GLIP European project, abiotic stress tolerance has been focused to

13 species such as M. truncatula, pea and chickpea (Gálvez et al., 2005; de Lorenzo et al.,

14 2007; Larrainzar et al., 2007; Merchan et al., 2007; Marino et al., 2008) leading to

15 identification of factors potentially involved in abiotic stress adaptation and tolerance.

16 The involvement of some genes in abiotic stress response has been already analysed in

17 different legumes. For instance, alfalfa over-expressing chloroplastic MnSOD showed

18 lower cold-induced membrane injuries (McKersie et al., 1996), although these

19 transgenic lines did not present better tolerance to drought stress (Rubio et al., 2002).

20 The transcriptional regulator, Alfin1, over-expressed in alfalfa was shown to regulate

21 endogenous $\mathrm{NaCl}$-inducible gene expression, resulting in salinity tolerance (Winicov

22 and Bastola, 1999). Similarly, a drought-responsive AP2-type transcription factor

23 induced several wax-related genes resulting in increased drought tolerance when over-

24 expressed in alfalfa (Aharoni et al., 2004; Zhang et al., 2005). In addition, the stress- 
1 inducible expression of AtDREB1A increases transpiration efficiency in peanut under

2 water-limiting conditions (Bhatnagar-Mathur et al., 2007).

$4 \quad 5.4$. Breeding for nitrogen fixation

\subsubsection{Induction of legume root nodules}

Nodulation is initiated by plant roots exuding flavonoid molecules into the soil (Ferguson and Mathesius, 2003). This attracts rhizobia to the roots and concomitantly stimulates them to synthesize a lipochito-oligosaccharide signaling molecule called Nod Factor (NF) (Caetano-Anollés and Gresshoff, 1991; Stacey et al., 2006; Oldroyd, 2007).

Using the model species L. japonicus and M. truncatula, and a predominantly mutantbased approach, many of the genes required for nodule development have now been elucidated (Stacey et al., 2006; see Fig. 2A). This includes genes encoding transmembrane LysM-type receptor kinases believed to be required for NF perception: LjNFR1 and LjNFR5 in L. japonicus, and MtNFP, MtLYK3 and LYK4 in M. truncatula (Ben Amor et al., 2003; Limpens et al., 2003; Madsen et al., 2003; Radutoiu et al., 2003; Arrighi et al., 2006). Subsequent to perception, NF signaling continues through a NBS-LRR receptor kinase, called LjSYMRK/MtDMI2 (Endre et al., 2002; Stracke et al., 2002). The signalling cascade then progresses via a number of genes, including those encoding potential potassium ion channels, MtDMI1, LjCASTOR and LjPOLLUX (Ané et al., 2004; Imaizumi-Anraku et al., 2005), putative nucleoporins, LjNUP133 and LjNUP85 (Kanamori et al., 2006; Saito et al., 2007), a calcium-calmodulin-dependent protein kinase, MtCCaMK (Lévy et al., 2004; Mitra et al., 2004), a cytokinin receptor, LjLHK1/MtCRE1 (Gonzalez-Rizzo et al., 2006; Murray et al., 2007; Oldroyd, 2007; Tirichine et al., 2007) and finally transcription factors, including MtNSP1, MtNSP2, MtERF and LjNIN (Schauser et al., 1999; Kaló et al., 2005; Smit et al., 2005; Middleton 
1 et al., 2007). These genes are all required for nodulation; the loss of any results in

2 reduced, or a complete lack of nodule formation.

3

4

6 Mutants unable to synthesize or perceive these factors exhibit increased nodule

7 numbers. The best known of these factors function in the plant's Autoregulation Of

8 Nodulation (AON) pathway (Caetano-Anollés and Gresshoff, 1991; Gresshoff, 2003;

9 Kinkema et al., 2006; see Fig. 2B). This pathway involves long-distance root-shoot

10 signalling initiated during nodule development by the synthesis of a root-derived signal.

11 Grafting experiments (Delves et al., 1986; Jiang and Gresshoff, 1997) have shown this

12 signal (named 'Q') travels to the shoot where it, or a product of its action, is perceived

13 by a LRR receptor kinase, called GmNARK/LjHAR1/MtSUNN (Krusell et al., 2002;

14 Men et al., 2002; Nishimura et al., 2002a; Searle et al., 2003; Schnabel et al., 2005).

15 Grafting studies have also shown that the gene, LjKLAVIER, has a shoot-specific role in

16 AON (Oka-Kira et al., 2005), but the identity of this gene remains unknown. Following

17 perception in the shoot, a novel shoot-derived inhibitor (named 'SDI') is synthesized and travels back down to the roots where it acts to inhibit further nodulation events

19 (Gresshoff and Delves, 1986). Gene chip and real time PCR analysis of leaves from inoculated or uninoculated soybean plants differing in GmNARK function, revealed a novel regulation of the octodecanoid pathway, suggesting jasmonic acid signaling is involved in AON (Kinkema and Gresshoff, 2008).

Root-specific AON genes have been identified in pea, PsNOD3 (Postma et al., 1988), and M. truncatula, MtRdn1 (J. Frugoli, personal communication), that are possibly involved in Q biosynthesis or translocation or SDI perception in the root. 
1 Genes homologous to those detailed above could be identified in faba bean mutant

2 collections (Duc and Picard, 1986; Duc, 1995), potentially leading to improved 3 symbiosis in crop lines.

Other factors that reduce nodule numbers include ethylene and nitrate (Carroll et 5 al., 1985a; 1985b; Ligero et al., 1991; Lee and Larue, 1992; Ferguson and Mathesius, 6 2003; Ferguson et al., 2005). Mutations that disrupt the plant's ability to perceive these 7 factors alleviate their inhibitory nature, resulting in increased nodule numbers (cf. 8 Penmetsa and Cook, 1997). This includes genes required for ethylene sensitivity and 9 response, such as LjETR1 and LjEIN2/MtEIN2 (e.g. Penmetsa et al., 2008). In addition, 10 nitrate-tolerant symbiosis (nts) mutants that form many nodules when grown under 11 inhibitory nitrate levels have been isolated in soybean and pea (Jacobsen and Feenstra, 12 1984; Carroll et al., 1985a; 1985b; Delves et al., 1986; Duc and Messager, 1989), but 13 nts genes not involved in AON remain to be cloned. Interestingly, the gene LjASTRAY, 14 which encodes a bZIP transcription factor with a RING-finger motif, regulates light and 15 photomorphogenic signalling and also nodulation, as loss-of-function mutant exhibit 16 increased nodule number (Nishimura et al., 2002b). Understanding the roles of the 17 above-mentioned regulatory genes will enable optimizing the symbiosis, resulting in tremendous agronomic impacts for faba bean.

\subsubsection{Molecular genetics of nodulation and nitrogen fixation in faba bean}

Faba bean forms indeterminate root nodules with the soil bacteria, Rhizobium

22 leguminosarum bv. viciae, and in many regions where effective rhizobia populations are 23 present, field inoculation is not practiced. Biodiversity in host-microbe populations has 24 been exploited to improve nitrogen fixation rates of faba bean (e.g. Mytton et al., 1977; 25 Mytton, 1984; Knaak et al., 1993). Recent molecular insights, including the 
1 identification of symbiotic genes in L. japonicus and M. truncatula, will enhance these

2 classical breeding approaches. The use of faba bean mutants that fail to nodulate ( $\left.\mathrm{Nod}^{-}\right)$,

3 excessively nodulate $\left(\mathrm{Nod}^{++}\right)$even in the presence of nitrate (nts), or are non-functional

4 (Fix ${ }^{-}$, i.e., fail to fix nitrogen), including those spontaneously occurring (sym-1; Duc and

5 Picard, 1986; Haser et al., 1992) or chemically induced (Duc, 1995), offer further

6 potential in this area. Similarly, the identity of numerous faba bean genes encoding

7 unknown nodule proteins (nodulins) and leghemoglobins (required for nitrogen

8 fixation) (Perlick and Pühler, 1993; Frühling et al., 1997; Schröder et al., 1997; Hohnjec

9 et al., 2000; Vieweg et al., 2004) should aid in efforts to improve nitrogen fixation via

10 coupling transgenic techniques with classical breeding methods.

\subsubsection{Application of functional genomics in faba bean}

Advances in genomic technology and insights could aid nodulation and nitrogen

14 fixation research in faba bean. Following similar work in cereals, it was discovered that

15 legume genome maps share broad similarity (called macro-synteny; Choi et al., 2004b).

16 Likewise, molecular markers in legume genomes (usually ESTs reflecting biochemical

17 functions) are found in similar chromosomal blocks. Thus, discovery of markers linked

18 to a certain phenotype, for instance, in M. truncatula may provide a tool to identify the

19 same characteristic in the otherwise unexplored faba bean. It therefore becomes critical

20 that molecular linkage maps of faba bean include both ESTs and phenotypes (including

21 QTLs) relating to nodulation, nitrogen use efficiency and nitrogen fixation, and that

22 variation for these phenotypes is mapped to such conserved EST markers. The recently

23 completed, and near-completed, genome sequences of G. $\max , M$. truncatula and $L$.

24 japonicus respectively, will greatly aid in this area of research 
1 (http://www.phytozome.net/soybean; http://www.medicago.org/genome/; Sato et al., 2 2008).

3

\section{6. Concluding Remarks}

The use of model legumes to investigate important grain legume traits has

6 already improved our knowledge on legume biology. In particular it allows important

7 breakthroughs in our understanding of nitrogen-fixing symbiosis, and begins to bring

8 clues to legume seed quality and resistance to biotic and abiotic stresses. The high level

9 of synteny and conservation that exist between most legume genomes should allow an

10 efficient transfer of all the knowledge that is being accumulated in these model legumes

11 to improve faba bean, a grain legume for which its large genome size limits the

12 development of post-genomic tools. Indeed, candidate genes identified by

13 transcriptomic, proteomic or map-based cloning can be transferred to elite cultivars of

14 faba bean after validation of its function by MAS or genetic transformation.

15 While the use of model legumes has already increased our knowledge on several

16 important aspects of grain legumes, many gaps remain in our understanding of legume

17 quality, nitrogen-fixing capacities and resistance to stresses. In parallel,

18 biotechnological improvements allow the development of different post-genomic tools

19 to facilitate the identification of genes and pathways, functional analysis of these genes

20 and the search for favourable alleles in germplasm collections. Although these tools are

21 expected to greatly help the transfer of important genes for crop improvement in a near

22 future, they are likely to be still insufficient. For the improvement of any trait, an

23 integration of knowledge coming from molecular biologists, plant physiologists, plant

24 pathologists, agronomists, applied breeders and experts on social-environmental impact,

25 involving multi-criteria decision-making programs, is required. Within the framework 
1 of the above mentioned GLIP project some advances have been made possible.

2 However, for real results "at the fork level", the recently created interdisciplinary

3 research networks, and others yet to come, need to be continued, which will require

4 extended commitment from funding agencies at the national and international levels.

6 Acknowledgments

7

8 This work was funded in part by the European Union Grain Legumes 9 Integrated Project (FOOD-CT-2004-506223), the Spanish Ministry of Education 10 (AGL2005-0274/AGR, AGL2008-01239/AGR), the Australian Research Council for 11 Centre of Excellence funding, UQ for strategic funds from the VC, DVCR and BACS 12 Faculty. N.R. is holder of a JAE Post-Doc Grant from CSIC. C.A.-I. wishes to 13 acknowledge the support provided by the Mobility Programme of the Spanish Ministry 14 of Education and Science. The authors thank center colleagues for comments and 15 support and in particular Dr. Walid Sadok, Judith Burstin, Pascal Marget and Marianne 16 Martinello, (INRA-UMRLEG, Dijon), for their help in compiling this review and Dr. K 17 Lindstrøm for developing Fig. 2A. The authors also would like to apologise for all the 18 important references that were not included due to length limitation.

\section{References}

21 Aharoni, A., Dixit, S., Jetter, R., Thoenes, E., van Arkel, G., Pereira, A., 2004. The 22 SHINE clade of AP2 domain transcription factors activates wax biosynthesis, alters 23 cuticle properties, and confers drought tolerance when overexpressed in Arabidopsis.

24 Plant Cell 16, 2463-2480. 
1 Ameline-Torregrosa, C., Cazaux, M., Danesh, D., Chardon, F., Cannon, S.B., Esquerré-

2 Tugayé, M.T., Dumas, B., Young, N.D., Samac, D.A., Huguet, T., Jacquet, C., 2008.

3 Genetic dissection of resistance to anthracnose and powdery mildew in Medicago

4 truncatula. Mol. Plant Microbe Interac. 21, 61-69.

5 Ané, J.M., Kiss, G.B., Riely, B.K., Penmetsa, R.V., Oldroyd, G.E.D., Ayax, C., Lévy,

6 J., Debellé, F., Baek, J.M., Kaló, P., Rosenberg, C., Roe, B.A., Long, S.R., Dénarié, J.,

7 Cook, D.R., 2004. Medicago truncatula DMI1 required for bacterial and fungal

8 symbioses in legumes. Science 303, 1364-1367.

9 Ané, J.M., Zhu, H., Frugoli, J., 2008. Recent Advances in Medicago truncatula

10 Genomics. Int. J. Plant Genomics 2008, Article ID 256597, 11 pages.

11 doi:10.1155/2008/256597.

12 Armengaud, P., Thiery, L., Buhot, N., Grenier-De March, G., Savouré, A., 2004.

13 Transcriptional regulation of proline biosynthesis in Medicago truncatula reveals

14 developmental and environmental specific features. Physiol. Plant. 120, 442-450.

15 Arrighi, J.F., Barre, A., Ben Amor, B., Bersoult, A., Soriano, L.C., Mirabella, R., de

16 Carvalho-Niebel, F., Journet, E.P., Ghérardi, M., Huguet, T., Geurts, R., Dénarié, J.,

17 Rougé, P., Gough, C., 2006. The Medicago truncatula lysin M motif-receptor-like

18 kinase gene family includes NFP and new nodule-expressed genes. Plant Physiol. 142,

$19 \quad 265-279$.

20 Aubert, G., Morin, J., Jacquin, F., Loridon, K., Quillet, M.C., Petit, A., Rameau, C.,

21 Lejeune-Hénaut, I., Huguet, T., Burstin, J., 2006. Functional mapping in pea, as an aid

22 to the candidate gene selection and for investigating synteny with the model legume

23 Medicago truncatula. Theor. Appl. Genet. 112, 1024-1041.

24 Ávila, C.M., Sillero, J.C., Rubiales, D., Moreno, M.T., Torres, A.M., 2003.

25 Identification of RAPD markers linked to the Uvf-1 gene conferring hypersensitive 
1 resistance against rust (Uromyces viciae-fabae) in Vicia faba L. Theor. Appl. Genet. $2 \quad 107,353-358$.

3 Ávila, C.M., Satovic, Z., Sillero, J.C., Rubiales, D., Moreno, M.T., Torres, A.M., 2004.

4 Isolate and organ-specific QTLs for ascochyta blight resistance in faba bean (Vicia faba

5 L.). Theor. Appl. Genet. 108, 1071-1078.

6 Babu, M., Gagarinova, A.G., Brandle, J.E., Wang, A., 2008. Association of the 7 transcriptional response of soybean plants with soybean mosaic virus systemic 8 infection. J. Gen. Virol. 89, 1069-1080.

9 Bailey-Serres, J., Voesenek, L., 2008. Flooding stress: Acclimations and genetic 10 diversity. Annu. Rev. Plant Biol. 59, 313-339.

11 Bañon, S., Fernández, J.A., Franco, J.A., Torrecillasa, A., Alarcón, J.J., Sánchez12 Blanco, M.J., 2004. Effects of water stress and night temperature preconditioning on 13 water relations and morphological and anatomical changes of Lotus creticus plants. Sci. 14 Hortic. 101, 333-342.

15 Barbetti, M.J., 2007. Resistance in annual Medicago spp. to Phoma medicaginis and 16 Leptosphaerulina trifolii and its relationship to induced production of a phytoestrogen.

17 Plant Disease 91, 239-244.

18 Barbetti, M.J., Allen, J.G., 2005. Association of Fusarium species, with potential for 19 mycotoxicosis, on pods of annual Medicago in Western Australia. Austr. J. Agric. Res. $20 \quad 56,279-284$

21 Bardel, J., Louwagie, M., Jaquinod, M., Jourdain, A., Luche, S., Rabilloud, T., 22 Macherel, D., Garin, J., Bourguignon, J., 2002. A survey of the plant mitochondrial 23 proteome in relation to development. Proteomics 2, 880-898.

24 Barker, D.B., Bianchi, S., Blondon, F., Dattée, Y., Duc, G., Essad, S., Flament, P., 25 Gallusci, P., Génier, P., Muel, X., Tourneur, J., Dénarié, J., Huguet, T., 1990. Medicago 
1 truncatula, a model plant for studying the molecular genetics of the Rhizobium-legume

2 symbiosis. Plant Mol. Biol. Rep. 8, 40-49.

3 Barnett, M.J., Toman, C.J., Fisher, R.F., Long, S.R., 2004. A dual-genome Symbiosis

4 Chip for coordinate study of signal exchange and development in a prokaryote-host

5 interaction. Proc. Natl. Acad. Sci. USA 101, 16636-16641.

6 Bastianelli, D., Grosjean, F., Peyronnet, C., Duparque, M., Regnier, J.M., 1998. Feeding

7 value of pea (Pisum sativum L.) - 1 Chemical composition of different categories of pea.

8 Animal Science 67, 609-619.

9 Ben Amor, B., Shaw, S.L., Oldroyd, G.E.D., Maillet, F., Penmetsa, R.V., Cook, D.R., 10 Long, S.R., Dénarié, J., Gough, C., 2003. The NFP locus of Medicago truncatula 11 controls an early step of Nod factor signal transduction upstream of a rapid calcium flux 12 and root hair deformation. Plant J. 34, 495-506.

13 Benedito, V.A., Torres-Jerez, I., Murray, J.D., Andriankaja, A., Allen, S., Kakar, K., 14 Wandrey, M., Verdier, J., Zuber, H., Ott, T., Moreau, S., Niebel, A., Frickey, T., 15 Weiller, G., He, J., Dai, X., Zhao, P.X., Tang, Y., Udvardi, M.K., 2008. A gene 16 expression atlas of the model legume Medicago truncatula. Plant J. 55, 504-513.

17 Bhatnagar-Mathur, P., Devi, M.J., Reddy, D.S., Lavanya, M., Vadez, V., Serraj, R., 18 Yamaguchi-Shinozaki, K., Sharma, K.K., 2007. Stress-inducible expression of At 19 DREB1A in transgenic peanut (Arachis hypogaea L.) increases transpiration efficiency 20 under water-limiting conditions. Plant Cell Rep. 26, 2071-2082.

21 Borsani, O., Díaz, P., Monza, J., 1999. Proline is involved in water stress responses of 22 Lotus corniculatus nitrogen fixing and nitrate fed plants. J. Plant Physiol. 155, 269-273.

23 Borsani, O., Díaz, P., Agius, M.F., Valpuesta, V., Monza, J., 2001. Water stress 24 generates an oxidative stress through the induction of a specific $\mathrm{Cu} / \mathrm{Zn}$ superoxide 25 dismutase in Lotus corniculatus leaves. Plant Sci. 161, 757-763. 
1 Böttinger, P., Steinmetz, A., Schieder, O., Pickardt, T., 2001. Agrobacterium-mediated

2 transformation of Vicia faba. Mol. Breeding 8, 243-254.

3 Bourgeois, M., Jacquin, F., Savois, V., Sommerer, N., Labas, V., Henry, C., Burstin, J.,

4 2009. Dissecting the proteome of pea mature seeds reveals the phenotypic plasticity of

5 seed protein composition. Proteomics 9, 254-271.

6 Boutin, S.R., Young, N.D., Olson, T.C., Yu, Z.H., Vallejos, C.E., Shoemaker, R.C.,

7 1995. Genome conservation among three legume genera detected with DNA markers.

8 Genome 38, 928-937.

9 Brandsaeter, L.O., Olsmo, A., Tronsmo, A.M., Fykse, H., 2002. Freezing resistance of

10 winter annual and biennial legumes at different developmental stages. Crop Sci. 42,

$11 \quad 437-443$.

12 Burstin, J., Marget, P., Huart, M., Moessner, A., Mangin, B., Duchene, C., Desprez, B.,

13 Munier-Jolain, N., Duc, G., 2007. Developmental genes have pleiotropic effects on

14 plant morphology and source capacity, eventually impacting on seed protein content

15 and productivity in pea. Plant Physiol. 144, 768-781.

16 Caetano-Anollés, G., Gresshoff, P.M., 1991. Plant genetic control of nodulation. Annu.

17 Rev. Microbiol. 45, 345-382.

18 Cannon, S.B., Sterck, L., Rombauts, S., Sato, S., Cheung, F., Gouzy, J., Wang, X.,

19 Mudge, J., Vasdewani, J., Schiex, T., Spannagl, M., Monaghan, E., Nicholson, C.,

20 Humphray, S.J., Schoof, H., Mayer, K.F., Rogers, J., Quetier, F., Oldroyd, G.E.D.,

21 Debellé, F., Cook, D.R., Retzel, E.F., Roe, B.A., Town, C.D., Tabata, S., Van de Peer,

22 Y., Young, N.D., 2006. Legume genome evolution viewed through the Medicago

23 truncatula and Lotus japonicus genomes. Proc. Natl. Acad. Sci. USA 103, 149592414964. 
1 Carroll, B.J., McNeil, D.L., Gresshoff, P.M., 1985a. Isolation and properties of soybean

2 (Glycine $\max$ L. Merr) mutants that nodulate in the presence of high nitrate 3 concentrations. Proc. Natl. Acad. Sci. USA 82, 4162-4166.

4 Carroll, B.J., McNeil, D.L., Gresshoff, P.M., 1985b. A supernodulation and nitrate5 tolerant symbiotic (NTS) soybean mutant. Plant Physiol. 78, 34-40.

6 Carter, E.B., Theodorou, M.K., Morris, P., 1997. Responses of Lotus corniculatus to 7 environmental change. I. Effects of elevated $\mathrm{CO} 2$, temperature and drought on growth 8 and plant development. New Phytol. 136, 245-253.

9 Castillejo, M.A., Maldonado, A., Rubiales, D., Jorrín, J.V., 2008. Proteomic studies of 10 legume responses to infection by Orobanche crenata. Proteómica 1, 134-135.

11 Castillejo, M.A., Maldonado, A.M., Dumas-Gaudot, E., Fernández-Aparicio, M., Susin, 12 R., Rubiales, D., Jorrín, J.V., 2009. Differential expression proteomics to investigate 13 responses and resistance to Orobanche crenata in Medicago truncatula. Plant Physiol. 14 submitted.

15 Chaves, M.M., Maroco, J.P., Pereira, J.S., 2003. Understanding plant responses to 16 drought: From genes to the whole plant. Funct. Plant Biol. 30, 239-264.

17 Choi, H.K., Kim, D., Uhm, T., Limpens, E., Lim, H., Mun, J.H., Kaló, P., Penmetsa, 18 R.V., Seres, A., Kulikova, O., Roe, B.A., Bisseling, T., Kiss, G.B., Cook, D.R., 2004a. 19 A sequence-based genetic map of Medicago truncatula and comparison of marker 20 colinearity with $M$. sativa. Genetics $166,1463-1502$.

21 Choi, H.K., Mun, J.H., Kim, D.J., Zhu, H., Baek, J.M., Mudge, J., Roe, B.A., Ellis, N., 22 Doyle, J., Kiss, G.B., Young, N.D., Cook, D.R., 2004b. Estimating genome conservation between crop and model legume species. Proc. Natl. Acad. Sci. USA 101, 15289-15294. 
1 Colbert, T., Till, B.J., Tompa, R., Reynolds, S., Steine, M.N., Yeung, A.T., McCallum,

2 C.M., Comai, L., Henikoff, S., 2001. High-throughput screening for induced point

3 mutations. Plant Physiol. 126, 480-484.

4 Colditz, F., Nyamsuren, O., Niehaus, K., Eubel, H., Braun, H.P., Krajinski, F., 2004.

5 Proteomic approach: identification of Medicago truncatula proteins induced in roots

6 after infection with the pathogenic oomycete Aphanomyces euteiches. Plant Mol. Biol.

$7 \quad 55,109-120$

8 Colditz, F., Braun, H.P., Jacquet, C., Niehaus, K., Krajinski, F., 2005. Proteomic

9 profiling unravels insights into the molecular background underlying increased 10 Aphanomyces euteiches-tolerance of Medicago truncatula. Plant Mol. Biol. 59, 38711406.

12 Colditz, F., Niehaus, K., Krajinski, F., 2007. Silencing of PR-10-like proteins in

13 Medicago truncatula results in an antagonistic induction of other PR proteins and in an

14 increased tolerance upon infection with the oomycete Aphanomyces euteiches. Planta $15 \quad 226,57-71$

16 Colebatch, G., Desbrosses, G., Ott, T., Krusell, L., Montanari, O., Kloska, S., Kopka, J., 17 Udvardi, M.K., 2004. Global changes in transcription orchestrate metabolic 18 differentiation during symbiotic nitrogen fixation in Lotus japonicus. Plant J. 39, 48719512.

20 Constantin, G.D., Krath, B.N., MacFarlane, S.A., Nicolaisen, M., Johansen, I.E., Lund, 21 O.S., 2004. Virus-induced gene silencing as a tool for functional genomics in a legume 22 species. Plant J. 40, 622-631.

23 Cooper, J.L., Till, B.J., Laport, R.G., Darlow, M.C., Kleffner, J.M., Jamai, A., El-

24 Mellouki, T., Liu, S., Ritchie, R., Nielsen, N., Bilyeu, K.D., Meksem, K., Comai, L., 
1 Henikoff, S., 2008. TILLING to detect induced mutations in soybean. BMC Plant Biol.

$28,9$.

3 Coyne, C.J., McClendon, M.T., Walling, J.G., Timmerman-Vaughan, G.M., Murray, S.,

4 Meksem, K., Lightfoot, D.A., Shultz, J.L., Keller, K.E., Martin, R.R., Inglis, D.A.,

5 Rajesh, P.N., McPhee, K.E., Weeden, N.F., Grusak, M.A., Li, C.M., Storlie, E.W.,

6 2007. Construction and characterization of two bacterial artificial chromosome libraries

7 of pea (Pisum sativum L.) for the isolation of economically important genes. Genome $8 \quad 50,871-875$.

9 Crane, C., Wright, E., Dixon, R.A., Wang, Z.Y., 2006. Transgenic Medicago truncatula 10 plants obtained from Agrobacterium tumefaciens-transformed roots and Agrobacterium 11 rhizogenes-transformed hairy roots. Planta 223, 1344-1354.

12 Curto, M., Ferro, N., Krajinski, F., Schlereth, A., Udvardi, M.K., Rubiales, D., 2007.

13 Real-time RT-PCR profiling of transcription factors in Medicago truncatula in response 14 to powdery mildew (Erysiphe pisi). Model Legumes Congress, Tunis, Tunisia, p. P67.

15 Dalmadi, A., Kaló, P., Jakab, J., Saskoi, A., Petrovics, T., Deák, G., Kiss, G.B., 2008. 16 Dwarf plants of diploid Medicago sativa carry a mutation in the gibberellin 3-beta17 hydroxylase gene. Plant Cell Rep. 27, 1271-1279.

18 Dalmais, M., Schmidt, J., Le Signor, C., Moussy, F., Burstin, J., Savois, V., Aubert, G.,

19 Brunaud, V., de Oliveira, Y., Guichard, C., Thompson, R., Bendahmane, A., 2008.

20 UTILLdb, a Pisum sativum in silico forward and reverse genetics tool. Genome Biol. 9, $21 \mathrm{R} 43$

22 de Lorenzo, L., Merchan, F., Blanchet, S., Megías, M., Frugier, F., Crespi, M., Sousa, 23 C., 2007. Differential expression of the TFIIIA regulatory pathway in response to salt 24 stress between Medicago truncatula genotypes. Plant Physiol. 145, 1521-1532. 
1 De Smet, I., Jurgens, G., 2007. Patterning the axis in plants-auxin in control. Curr.

2 Opin. Genet. Dev. 17, 337-343.

3 Delves, A.C., Mathews, A., Day, D.A., Carter, A.S., Carroll, B.J., Gresshoff, P.M., 4 1986. Regulation of the soybean-Rhizobium nodule symbiosis by shoot and root factors.

$5 \quad$ Plant Physiol. 82, 588-590.

6 Devos, K.M., Beales, J., Nagamura, Y., Sasaki, T., 1999. Arabidopsis-rice: Will 7 colinearity allow gene prediction across the eudicot-monocot divide? Genome Res. 9, $8 \quad 825-829$.

9 Díaz, P., Monza, J., Márquez, A., 2005. Drought and saline stress. In: Márquez, A.J., 10 Stougaard, J., Udvardi, M.K., Parniske, M., Spaink, H.P., Saalbach, G., Webb, K.J., 11 Chiurazzi, M. (Eds.), Lotus Japonicus Handbook, Springer, Dordretch, Germany, pp391250.

13 Dié, J.V., Dita, M.A., Krajinski, F., González-Verdejo, C.I., Rubiales, D., Moreno, 14 M.T., Román, B., 2007. Identification by suppression subtractive hybridization and 15 expression analysis of Medicago truncatula putative defence genes in response to 16 Orobanche crenata parasitization. Physiol. Mol. Plant Pathol. 70, 49-59.

17 Dita, M.A., Dié, J.V., Román, B., Krajinski, F., Küster, H., Moreno, M.T., Cubero, J.I., 18 Rubiales, D., 2009. Gene expression profiling of Medicago truncatula roots in response 19 to the parasitic plant Orobanche crenata. Planta submitted.

20 Djemel, N., Guedon, D., Lechevalier, A., Salon, C., Miquel, M., Prosperi, J.M., Rochat, 21 C., Boutin, J.P., 2005. Development and composition of the seeds of nine genotypes of 22 the Medicago truncatula species complex. Plant Physiol. Biochem. 43, 557-566.

23 Duc, G., 1995. Mutagenesis of faba bean (Vicia faba L.) and the identificaion of 5 24 different genes controlling no nodulation, ineffective nodulation or supernodulation. 25 Euphytica 83, 147-152. 
1 Duc, G., 2004. Seed composition of Medicago truncatula (line J5), compared to other

2 seed legumes. 5th European Conference on grain legumes/ 2nd ICLGG Conference,

3 Dijon, France, p 404.

4 Duc, G., Picard, J., 1986. Note on the presence of the sym1 gene in Vicia faba 5 hampering its symbiosis with Rhizobium leguminosarum. Euphytica 35, 61-64.

6 Duc, G., Messager, A., 1989. Mutagenesis of pea (Pisum sativum L.) and the isolation 7 of mutants for nodulation and nitrogen-fixation. Plant Sci. 60, 207-213.

8 Duc, G., Marget, P., Esnault, R., Le Guen, J., Bastianelli, D., 1999. Genetic variability

9 for feeding value of faba bean seeds (Vicia faba): Comparative chemical composition of

10 isogenics involving zero-tannin and zero-vicine genes. J. Agric. Sci. 133, 185-196.

11 El Yahyaoui, F., Küster, H., Ben Amor, B., Hohnjec, N., Pühler, A., Becker, A., Gouzy,

12 J., Vernié, T., Gough, C., Niebel, A., Godiard, L., Gamas, P., 2004. Expression profiling

13 in Medicago truncatula identifies more than 750 genes differentially expressed during 14 nodulation, including many potential regulators of the symbiotic program. Plant 15 Physiol. 136, 3159-3176.

16 Ellis, T.H.N., Poyser, S.J., 2002. An integrated and comparative view of pea genetic and 17 cytogenetic maps. New Phytol. 153, 17-25.

18 Ellwood, S.R., Kamphuis, L.G., Oliver, R.P., 2006. Identification of sources of 19 resistance to Phoma medicaginis isolates in Medicago truncatula SARDI core 20 collection accessions, and multigene differentiation of isolates. Phytopathology 96, $21 \quad 1330-1336$.

22 Endre, G., Kereszt, A., Kevei, Z., Mihacea, S., Kaló, P., Kiss, G.B., 2002. A receptor 23 kinase gene regulating symbiotic nodule development. Nature 417, 962-966.

24 Ferguson, B.J., Mathesius, U., 2003. Signaling interactions during nodule development.

25 J. Plant Growth Regul. 22, 47-72. 
1 Ferguson, B.J., Wiebe, E.M.K., Emery, R.J.N., Guinel, F.C., 2005. Cytokinin

2 accumulation and an altered ethylene response mediate the pleiotropic phenotype of the

3 pea nodulation mutant R50 (sym16). Can. J. Bot. 83, 989-1000.

4 Fernández-Aparicio, M., Pérez-De-Luque, A., Prats, E., Rubiales, D., 2008. Variability

5 of interactions between barrel medic (Medicago truncatula) genotypes and Orobanche

6 species. Ann. Appl. Biol. 153, 117-126.

7 Fernández-Aparicio, M., Flores, F., Rubiales, D., 2009. Recognition of root exudates by

8 seeds of broomrape (Orobanche and Phelipanche) species. Ann. Bot. 103, 423-431.

9 Fondevilla, S., Krajinski, F., Küster, H., Torres, A.M., Moreno, M.T., Rubiales, D.,

10 2008. Identificación de genes expresados diferencialmente en la resistencia a

11 Mycosphaerella pinodes en guisante. Conference SEG, Cordoba, Spain.

12 Foster-Hartnett, D., Danesh, D., Penuela, S., Sharopova, N., Endre, G., Vandenbosch, 13 K.A., Young, N.D., Samac, D.A., 2007. Molecular and cytological responses of

14 Medicago truncatula to Erysiphe pisi. Mol. Plant Pathol. 8, 307-319.

15 Frühling, M., Roussel, H., Gianinazzi-Pearson, V., Pühler, A., Perlick, A.M., 1997. The

16 Vicia faba leghemoglobin gene VfLb29 is induced in root nodules and in roots colonized

17 by the arbuscular mycorrhizal fungus Glomus fasciculatum. Mol. Plant Microbe Interac.

$18 \quad 10,124-131$.

19 Furutani, N., Yamagishi, N., Hidaka, S., Shizukawa, Y., Kanematsu, S., Kosaka, Y., 20 2007. Soybean mosaic virus resistance in transgenic soybean caused by post21 transcriptional gene silencing. Breeding Sci. 57, 123-128.

22 Gálvez, L., González, E.M., Arrese-Igor, C., 2005. Evidence for carbon flux shortage 23 and strong carbon/nitrogen interactions in pea nodules at early stages of water stress. J.

24 Exp. Bot. 56, 2551-2561. 
1 Gallardo, K., Le Signor, C., Vandekerckhove, J., Thompson, R.D., Burstin, J., 2003.

2 Proteomics of Medicago truncatula seed development establishes the time frame of

3 diverse metabolic processes related to reserve accumulation. Plant Physiol. 133, 6644682.

5 Gallardo, K., Kurt, C., Thompson, R., Ochatt, S., 2006. In vitro culture of immature $M$.

6 truncatula grains under conditions permitting embryo development comparable to that 7 observed in vivo. Plant Sci. 170, 1052-1058.

8 Gallardo, K., Firnhaber, C., Zuber, H., Hericher, D., Belghazi, M., Henry, C., Küster,

9 H., Thompson, R., 2007. A combined proteome and transcriptome analysis of 10 developing Medicago truncatula seeds: Evidence for metabolic specialization of 11 maternal and filial tissues. Mol. Cell Proteomics 6, 2165-2179.

12 Gonzales, M.D., Archuleta, E., Farmer, A., Gajendran, K., Grant, D., Shoemaker, R.C., 13 Beavis, W.D., Waugh, M.E., 2005. The Legume Information System (LIS): An 14 integrated information resource for comparative legume biology. Nucleic Acids Res. 33, $15 \quad 660-665$.

16 Gonzalez-Rizzo, S., Crespi, M., Frugier, F., 2006. The Medicago truncatula CRE1 17 cytokinin receptor regulates lateral root development and early symbiotic interaction 18 with Sinorhizobium meliloti. Plant Cell 18, 2680-2693.

19 González, E.M., Gordon, A.J., James, C.L., Arrese-Igor, C., 1995. The role of sucrose 20 synthase in the response of soybean nodules to drought. J. Exp. Bot. 46, 1515-1523.

21 González, E.M., Aparicio-Tejo, P.M., Gordon, A.J., Minchin, F.R., Royuela, M., 22 Arrese-Igor, C., 1998. Water-deficit effects on carbon and nitrogen metabolism of pea 23 nodules. J. Exp. Bot. 49, 1705-1714. 
1 Greene, S., Hughes, S.J., Nair, R., Huguet, T., Aouani, M.E., Prosperi, J.M., Delalande,

2 M., 2006. Wild accessions/populations. In: Mathesius, U., Journet, E.P., Sumner, L.W.

3 (Eds.), The Medicago truncatula handbook. http://www.noble.org/MedicagoHandbook)

4 Gresshoff, P.M., 2003. Post-genomic insights into plant nodulation symbioses. Genome

5 Biol. 4, 201.

6 Gresshoff, P.M., Delves, A.C., 1986. Plant genetic approaches to symbiotic nodulation

7 and nitrogen fixation in legumes. Plant Gene Res. 3, 159-206.

8 Gruber, V., Blanchet, S., Diet, A., Zahaf, O., Boualem, A., Kakar, K., Alunni, B.,

9 Udvardi, M.K., Frugier, F., Crespi, M., 2009. Identification of transcription factors

10 involved in root apex responses to salt stress in Medicago truncatula. Mol. Genet.

11 Genomics 1, 55-66.

12 Gutiérrez, N., Ávila, C.M., Duc, G., Marget, P., Suso, M.J., Moreno, M.T., Torres,

13 A.M., 2006. CAPs markers to assist selection for low vicine and convicine contents in

14 faba bean (Vicia faba L.). Theor. Appl. Genet. 114, 59-66.

15 Gutiérrez, N., Ávila, C.M., Rodríguez-Suárez, C., Moreno, M.T., Torres, A.M., 2007.

16 Development of SCAR markers linked to a gene controlling absence of tannins in faba

17 bean. Mol. Breeding 19, 305-314.

18 Gutiérrez, N., Ávila, C.M., Moreno, M.T., Torres, A.M., 2008a. Development of SCAR

19 markers linked to zt-2, one of the genes controlling absence of tannins in faba bean.

20 Austr. J. Agric. Res. 59, 62-68.

21 Gutiérrez, N., Palomino, C., Cruz-Izquierdo, S., Ávila, C.M., Torres, A.M., 2008b.

22 Empleo de la genómica comparativa em la mejora de las habas (Vicia faba). Actas

23 Horticultura 51, pp. 269-270.

24 Handberg, K., Stougaard, J., 1992. Lotus japonicus, an autogamous, diploid legume

25 species for classical and molecular genetics. Plant J. 2, 487-496. 
1 Hasegawa, P.M., Bressan, R.A., Zhu, J.K., Bohnert, H.J., 2000. Plant cellular and

2 molecular responses to high salinity. Annu. Rev. Plant Phys. 51, 463-499.

3 Haser, A., Robinson, D.L., Duc, G., Vance, C.P., 1992. A mutation in Vicia faba results

4 in ineffective nodules with impaired bacteroid differentiation and reduced synthesis of

$5 \quad$ late nodulins J. Exp. Bot. 43, 1397-1407.

6 Hayashi, S., Gresshoff, P.M., Kinkema, M., 2008. Molecular analysis of lipoxygenases

7 associated with nodule development in soybean. Mol. Plant Microbe Interac. 21, 8438853

9 Heckmann, A.B., Lombardo, F., Miwa, H., Perry, J.A., Bunnewell, S., Parniske, M., 10 Wang, T.L., Downie, J.A., 2006. Lotus japonicus nodulation requires two GRAS 11 domain regulators, one of which is functionally conserved in a non-legume. Plant 12 Physiol. 142, 1739-1750.

13 Heino, P., Palva, E.T., 2003. Signal transduction in plant cold acclimation. In: H. Hirt, 14 K. Shinozaki (Eds.) Plant responses to abiotic stress. Topics in Current Genetics volume 15 4. Springer-Verlag, Berlin, pp. 151-186.

16 Hekneby, M., Antolin, M.C., Sanchez-Diaz, M., 2006. Frost resistance and biochemical 17 changes during cold acclimation in different annual legumes. Environ. Exp. Bot. 55, $18 \quad 305-314$.

19 Hoffmann, D., Jiang, Q., Men, A., Kinkema, M., Gresshoff, P.M., 2007. Nodulation 20 deficiency caused by fast neutron mutagenesis of the model legume Lotus japonicus. J. 21 Plant Physiol. 164, 460-469.

22 Hohnjec, N., Küster, H., Albus, U., Frosch, S.C., Becker, J.D., Pühler, A., Perlick, 23 A.M., Frühling, M., 2000. The broad bean nodulin VfENOD18 is a member of a novel 24 family of plant proteins with homologies to the bacterial MJ0577 superfamily. Mol. 25 Gen. Genet. 264, 241-250. 
1 Hohnjec, N., Vieweg, M.F., Pühler, A., Becker, A., Küster, H., 2005. Overlaps in the

2 transcriptional profiles of Medicago truncatula roots inoculated with two different

3 Glomus fungi provide insights into the genetic program activated during arbuscular

4 mycorrhiza. Plant Physiol. 137, 1283-1301.

5 Horst, I., Welham, T., Kelly, S., Kaneko, T., Sato, S., Tabata, S., Parniske, M., Wang,

6 T.L., 2007. TILLING mutants of Lotus japonicus reveal that nitrogen assimilation and

7 fixation can occur in the absence of nodule-enhanced sucrose synthase. Plant Physiol.

$8 \quad 144,806-820$.

9 Hougaard, B.K., Madsen, L.H., Sandal, N., de Carvalho Moretzsohn, M., Fredslund, J.,

10 Schauser, L., Nielsen, A.M., Rohde, T., Sato, S., Tabata, S., Bertioli, D.J., Stougaard, J.,

11 2008. Legume anchor markers link syntenic regions between Phaseolus vulgaris, Lotus

12 japonicus, Medicago truncatula and Arachis. Genetics 179, 2299-2312.

13 Humphry, M.E., Konduri, V., Lambrides, C.J., Magner, T., McIntyre, C.L., Aitken,

14 E.A.B., Liu, C.J., 2002. Development of a mungbean (Vigna radiata) RFLP linkage

15 map and its comparison with lablab (Lablab purpureus) reveals a high level of

16 colinearity between the two genomes. Theor. Appl. Genet. 105, 160-166.

17 Imaizumi-Anraku, H., Takeda, N., Charpentier, M., Perry, J., Miwa, H., Umehara, Y., 18 Kouchi, H., Murakami, Y., Mulder, L., Vickers, K., Pike, J., Downie, J.A., Wang, T., 19 Sato, S., Asamizu, E., Tabata, S., Yoshikawa, M., Murooka, Y., Wu, G.J., Kawaguchi, 20 M., Kawasaki, S., Parniske, M., Hayashi, M., 2005. Plastid proteins crucial for 21 symbiotic fungal and bacterial entry into plant roots. Nature 433, 527-531.

22 Jacobsen, E., Feenstra, W.J., 1984. A new pea mutant with efficient nodulation in the 23 presence of nitrate. Plant Sci. Lett. 33, 337-344.

24 Jiang, Q.Y., Gresshoff, P.M., 1997. Classical and molecular genetics of the model 25 legume Lotus japonicus. Mol. Plant Microbe Interac. 10, 59-68. 
1 Jones, H., 2004. What is water use efficiency? In: Bacon, M.A. (Ed.), Water use

2 efficiency in plant biology. Blackwell Publishing, oxford, pp. 27-41.

3 Jones, J.D.G., Dangl, J.L., 2006. The plant immune system. Nature 444, 323-329.

4 Julier, B., Huguet, T., Chardon, F., Ayadi, R., Pierre, J.B., Prosperi, J.M., Barre, P., 5 Huyghe, C., 2007. Identification of quantitative trait loci influencing aerial 6 morphogenesis in the model legume Medicago truncatula. Theor. Appl. Genet. 114, $7 \quad 1391-1406$.

8 Kachroo, A., Fu, D.Q., Havens, W., Navarre, D., Kachroo, P., Ghabrial, S.A., 2008. An

9 oleic acid-mediated pathway induces constitutive defense signaling and enhanced 10 resistance to multiple pathogens in soybean. Mol. Plant Microbe Interac. 21, 564-575.

11 Kaga, A., Ishii, T., Tsukimoto, K., Tokoro, E., Kamijima, O., 2000. Comparative 12 molecular mapping in Ceratotropis species using an interspecific cross between azuki 13 bean (Vigna angularis) and rice bean (V. umbellata). Theor. Appl. Genet. 100, 207-213.

14 Kaimoyo, E., VanEtten, H.D., 2008. Inactivation of pea genes by RNAi supports the 15 involvement of two similar O-methyltransferases in the biosynthesis of (+)-pisatin and 16 of chiral intermediates with a configuration opposite that found in (+)-pisatin. 17 Phytochemistry 69, 76-87.

18 Kakar, K., Wandrey, M., Czechowski, T., Gaertner, T., Scheible, W.R., Stitt, M., 19 Torres-Jerez, I., Xiao, Y., Redman, J.C., Wu, H.C., Cheung, F., Town, C.D., Udvardi, 20 M.K., 2008. A community resource for high-throughput quantitative RT-PCR analysis 21 of transcription factor gene expression in Medicago truncatula. Plant Methods 4, 18.

22 Kaló, P., Endre, G., Zimányi, L., Csanádi, G., Kiss, G.B., 2000. Construction of an improved linkage map of diploid alfalfa (Medicago sativa). Theor. Appl. Genet. 100, 641-657. 
1 Kaló, P., Seres, A., Taylor, S.A., Jakab, J., Kevei, Z., Kereszt, A., Endre, G., Ellis, T.H.,

2 Kiss, G.B., 2004. Comparative mapping between Medicago sativa and Pisum sativum.

3 Mol. Genet. Genomics 272, 235-246.

4 Kaló, P., Gleason, C., Edwards, A., Marsh, J., Mitra, R.M., Hirsch, S., Jakab, J., Sims,

5 S., Long, S.R., Rogers, J., Kiss, G.B., Downie, J.A., Oldroyd, G.E.D., 2005. Nodulation

6 signaling in legumes requires NSP2, a member of the GRAS family of transcriptional

7 regulators. Science 308, 1786-1789.

8 Kamphuis, L.G., Lichtenzveig, J., Oliver, R.P., Ellwood, S.R., 2008. Two alternative

9 recessive quantitative trait loci influence resistance to spring black stem and leaf spot in

10 Medicago truncatula. BMC Plant Biol. 8, 30.

11 Kanamori, N., Madsen, L.H., Radutoiu, S., Frantescu, M., Quistgaard, E.M., Miwa, H., 12 Downie, J.A., James, E.K., Felle, H.H., Haaning, L.L., Jensen, T.H., Sato, S., 13 Nakamura, Y., Tabata, S., Sandal, N., Stougaard, J., 2006. A nucleoporin is required for 14 induction of $\mathrm{Ca}^{2+}$ spiking in legume nodule development and essential for rhizobial and 15 fungal symbiosis. Proc. Natl. Acad. Sci. USA 103, 359-364.

16 Kawaguchi, M., Imaizumi-Anraku, H., Koiwa, H., Niwa, S., Ikuta, A., Syono, K., Akao, 17 S., 2002. Root, root hair, and symbiotic mutants of the model legume Lotus japonicus. 18 Mol. Plant Microbe Interac. 15, 17-26.

19 Kereszt, A., Li, D., Indrasumunar, A., Nguyen, C.D., Nontachaiyapoom, S., Kinkema, 20 M., Gresshoff, P.M., 2007. Agrobacterium rhizogenes-mediated transformation of 21 soybean to study root biology. Nat. Protoc. 2, 948-952.

22 Kevei, Z., Seres, A., Kereszt, A., Kaló, P., Kiss, P., Tóth, G., Endre, G., Kiss, G.B., 2005. Significant microsynteny with new evolutionary highlights is detected between

24 Arabidopsis and legume model plants despite the lack of macrosynteny. Mol. Genet.

25 Genomics 274, 644-657. 
1 Kinkema, M., Gresshoff, P.M., 2008. Investigation of downstream signals of the

2 soybean autoregulation of nodulation receptor kinase GmNARK. Mol. Plant Microbe 3 Interac. 21, 1337-1348.

4 Kinkema, M., Scott, P.T., Gresshoff, P.M., 2006. Legume nodulation: successful 5 symbiosis through short- and long-distance signalling. Funct. Plant Biol. 33, 707-721.

6 Knaak, C., Roskothen, P., Röbbelen, G., 1993. Symbiotic efficiency of Vicia faba

7 genotypes after field inoculation with different strains of Rhizobium leguminosarum 8 preselected in greenhouse tests. J. Plant Physiol. 141, 49-53.

9 Kouchi, H., Shimomura, K., Hata, S., Hirota, A., Wu, G.J., Kumagai, H., Tajima, S., 10 Suganuma, N., Suzuki, A., Aoki, T., Hayashi, M., Yokoyama, T., Ohyama, T., 11 Asamizu, E., Kuwata, C., Shibata, D., Tabata, S., 2004. Large-scale analysis of gene 12 expression profiles during early stages of root nodule formation in a model legume, 13 Lotus japonicus. DNA Res. 11, 263-274.

14 Krusell, L., Madsen, L.H., Sato, S., Aubert, G., Genua, A., Szczyglowski, K., Duc, G., 15 Kaneko, T., Tabata, S., de Bruijn, F., Pajuelo, E., Sandal, N., Stougaard, J., 2002. Shoot 16 control of root development and nodulation is mediated by a receptor-like kinase. 17 Nature 420, 422-426.

18 Kubo, M., Ueda, H., Park, P., Kawaguchi, M., Sugimoto, Y., 2009. Reactions of Lotus 19 japonicus ecotypes and mutants to root parasitic plants. J. Plant Physiol. 166, 353-362

20 Kulikova, O., Gualtieri, G., Geurts, R., Kim, D.J., Cook, D.R., Huguet, T., de Jong, 21 J.H., Fransz, P.F., Bisseling, T., 2001. Integration of the FISH pachytene and genetic 22 maps of Medicago truncatula. Plant J. 27, 49-58.

23 Küster, H., Hohnjec, N., Krajinski, F., El, Y.F., Manthey, K., Gouzy, J., Dondrup, M., 24 Meyer, F., Kalinowski, J., Brechenmacher, L., van Tuinen, D., Gianinazzi-Pearson, V., 25 Pühler, A., Gamas, P., Becker, A., 2004. Construction and validation of cDNA-based 
1 Mt6k-RIT macro- and microarrays to explore root endosymbioses in the model legume

2 Medicago truncatula. J. Biotechnol. 108, 95-113.

3 Larrainzar, E., Wienkoop, S., Weckwerth, W., Ladrera, R., Arrese-Igor, C., González,

4 E.M., 2007. Medicago truncatula root nodule proteome analysis reveals differential

5 plant and bacteroid responses to drought stress. Plant Physiol. 144, 1495-1507.

6 Le, B.H., Wagmaister, J.A., Kawashima, T., Bui, A.Q., Harada, J.J., Goldberg, R.B., 7 2007. Using genomics to study legume seed development. Plant Physiol. 144, 562-574.

8 Le Signor, C., Gallardo, K., Prosperi, J.M., Salon, C., Quillien, L., Thompson, R., Duc,

9 G., 2005. Genetic diversity for seed protein composition in Medicago truncatula. Plant 10 Genet. Resour. 3, 59-71.

11 Lee, H.S., Kim, H.J., An, C.S., 2004. Cloning and expression analysis of 2-on-2 12 hemoglobin from soybean. J. Plant Biol. 47, 92-98.

13 Lee, J.M., Grant, D., Vallejos, C.E., Shoemaker, R.C., 2001. Genome organization in 14 dicots. II. Arabidopsis as a "bridging species" to resolve genome evolution events 15 among legumes. Theor. Appl. Genet. 103, 765-773.

16 Lee, K.H., Larue, T.A., 1992. Ethylene as a possible mediator of light-induced and 17 nitrate-induced inhibition of nodulation of Pisum sativum L. cv sparkle. Plant Physiol. $18 \quad 100,1334-1338$.

19 Lejeune-Hénaut, I., Hanocq, E., Béthencourt, L., Fontaine, V., Delbreil, B., Morin, J., 20 Petit, A., Devaux, R., Boilleau, M., Stempniak, J.J., Thomas, M., Lainé, A.L., Foucher, 21 F., Baranger, A., Burstin, J., Rameau, C., Giauffret, C., 2008. The flowering locus $\mathrm{Hr}$ 22 colocalizes with a major QTL affecting winter frost tolerance in Pisum sativum L. 23 Theor. Appl. Genet. 116, 1105-1116.

24 Lemontey, C., Mousset-Declas, C., Munier-Jolain, N., Boutin, J.P., 2000. Maternal 25 genotype influences pea seed size by controlling both mitotic activity during early 
1 embryogenesis and final endoreduplication level/cotyledon cell size in mature seed. J.

2 Exp. Bot. 51, 167-175.

3 Lévy, J., Bres, C., Geurts, R., Chalhoub, B., Kulikova, O., Duc, G., Journet, E.P., Ané,

4 J.M., Lauber, E., Bisseling, T., Dénarié, J., Rosenberg, C., Debellé, F., 2004. A putative

$5 \mathrm{Ca}^{2+}$ and calmodulin-dependent protein kinase required for bacterial and fungal

6 symbioses. Science 303, 1361-1364.

7 Ligero, F., Caba, J.M., Lluch, C., Olivares, J., 1991. Nitrate inhibition of nodulation can

8 be overcome by the ethylene inhibitor aminoethoxyvinylglycine. Plant Physiol. 97, $9 \quad 1221-1225$.

10 Limami, A.M., Ricoult, C., Planchet, E., González, E.M., Ladrera, R., Larrainzar, E., 11 Arrese-Igor, C., Merchan, F., Crespi, M., Frugier, F., 2006. Response of Medicago 12 truncatula to abiotic stress. In: Mathesius, U., Journet, E.P., Sumner, L.W. (Eds.), The 13 Medicago truncatula handbook. (http://www.noble.org/MedicagoHandbook)

14 Limpens, E., Franken, C., Smit, P., Willemse, J., Bisseling, T., Geurts, R., 2003. LysM

15 domain receptor kinases regulating rhizobial Nod factor-induced infection. Science 302, $16 \quad 630-633$.

17 Limpens, E., Ramos, J., Franken, C., Raz, V., Compaan, B., Franssen, H., Bisseling, T., 18 Geurts, R., 2004. RNA interference in Agrobacterium rhizogenes-transformed roots of 19 Arabidopsis and Medicago truncatula. J. Exp. Bot. 55, 983-992.

20 Lombari, P., Ercolano, E., El Alaoui, H., Chiurazzi, M., 2003. A new transformation21 regeneration procedure in the model legume Lotus japonicus: root explants as a source 22 of large numbers of cells susceptible to Agrobacterium-mediated transformation. Plant 23 Cell Rep. 21, 771-777. 
1 López, M., Herrera-Cervera, J.A., Iribarne, C., Tejera, N.A., Lluch, C., 2008. Growth

2 and nitrogen fixation in Lotus japonicus and Medicago truncatula under $\mathrm{NaCl}$ stress:

3 Nodule carbon metabolism. J. Plant Physiol. 165, 641-650.

4 Loridon, K., McPhee, K., Morin, J., Dubreuil, P., Pilet-Nayel, M.L., Aubert, G.,

5 Rameau, C., Baranger, A., Coyne, C., Lejeune-Hénaut, I., Burstin, J., 2005.

6 Microsatellite marker polymorphism and mapping in pea (Pisum sativum L.). Theor.

$7 \quad$ Appl. Genet. 111, 1022-1031.

8 Lozano-Baena, M.D., Prats, E., Moreno, M.T., Rubiales, D., Pérez-de-Luque, A., 2007.

9 Medicago truncatula as a model for nonhost resistance in legume-parasitic plant 10 interactions. Plant Physiol. 145, 437-449.

11 Ma, W., Smigel, A., Tsai, Y.C., Braam, J., Berkowitz, G.A., 2008. Innate immunity 12 signaling: Cytosolic $\mathrm{Ca}^{2+}$ elevation is linked to downstream nitric oxide generation 13 through the action of calmodulin or a calmodulin-like protein. Plant Physiol. 148, 81814828

15 Madrid, E., Gil, J., Krajinski, F., Schlereth, A., Rubiales, D., 2008. Perfil de expresión 16 de factores de transcripción en la interacción interacción Medicago truncatula17 Uromyces striatus. Conference SEG, Cordoba, Spain.

18 Madsen, E.B., Madsen, L.H., Radutoiu, S., Olbryt, M., Rakwalska, M., Szczyglowski,

19 K., Sato, S., Kaneko, T., Tabata, S., Sandal, N., Stougaard, J., 2003. A receptor kinase 20 gene of the LysM type is involved in legume perception of rhizobial signals. Nature $21425,637-640$.

22 Maeda, D., Ashida, K., Iguchi, K., Chechetka, S.A., Hijikata, A., Okusako, Y., Deguchi, 23 Y., Izui, K., Hata, S., 2006. Knockdown of an arbuscular mycorrhiza-inducible 24 phosphate transporter gene of Lotus japonicus suppresses mutualistic symbiosis. Plant 25 Cell Physiol 47, 807-817. 
1 Marino, D., Hohnjec, N., Küster, H., Moran, J.F., González, E.M., Arrese-Igor, C.,

2 2008. Evidence for transcriptional and post-translational regulation of sucrose synthase

3 in pea nodules by the cellular redox state. Mol. Plant Microbe Interac. 21, 622-630.

4 Maroof, M.A.S., Jeong, S.C., Gunduz, I., Tucker, D.M., Buss, G.R., Tolin, S.A., 2008a.

5 Pyramiding of soybean mosaic virus resistance genes by marker-assisted selection. Crop

$6 \quad$ Sci. $48,517-526$.

7 Maroof, M.A.S., Tucker, D.M., Tolin, S.A., 2008b. Genomics of viral-soybean

8 interactions. Gen. Genomics Soybean, 293-319.

9 Mathews, A., Carroll, B.J., Gresshoff, P.M., 1989. Development of Bradyrhizobium

10 infections in supernodulating and non-nodulating mutants of soybean (Glycine max L.

11 Merrill). Protoplasma 150, 40-47.

12 McKersie, B.D., Chen, Y.R., Debeus, M., Bowley, S.R., Bowler, C., Inzé, D., Dhalluin,

13 K., Botterman, J., 1993. Superoxide dismutase enhances tolerance of freezing stress in

14 transgenic alflafa (Medicago sativa L.). Plant Physiol. 103, 1155-1163.

15 McKersie, B.D., Bowley, S.R., Harjanto, E., Leprince, O., 1996. Water-deficit tolerance 16 and field performance of transgenic alfalfa overexpressing superoxide dismutase. Plant 17 Physiol. 111, 1177-1181.

18 McKersie, B.D., Murnaghan, J., Jones, K.S., Bowley, S.R., 2000. Iron-superoxide 19 dismutase expression in transgenic alfalfa increases winter survival without a detectable 20 increase in photosynthetic oxidative stress tolerance. Plant Physiol. 122, 1427-1437.

21 Meixner, C., Vegvari, G., Ludwig-Müller, J., Gagnon, H., Steinkellner, S., Staehelin, 22 C., Gresshoff, P., Vierheilig, H., 2007. Two defined alleles of the LRR receptor kinase 23 GmNARK in supernodulating soybean govern differing autoregulation of 24 mycorrhization. Physiol. Plant. 130, 261-270. 
1 Men, A.E., Laniya, T.S., Searle, I.R., Iturbe-Ormaetxe, I., Hussain, A.K.M., Gresshoff,

2 I., Jiang, Q., Carroll, B.J., Gresshoff, P.M., 2002. Fast neutron mutagenesis of soybean

3 (Glycine soja [L.]) produces a supernodulating mutant containing a large deletion.

4 Genome Lett. 3, 147-155.

5 Menancio-hautea, D., Fatokun, C.A., Kumar, L., Danesh, D., Young, N.D., 1993.

6 Comparative genome analysis of mungbean (Vigna radiata L. Wilczek) and cowpea (V.

7 unguiculata L. Walpers) using RFLP mapping data. Theor. Appl. Genet. 86, 797-810.

8 Merchan, F., Breda, C., Hormaeche, J.P., Sousa, C., Kondorosi, A., Aguilar, O.M.,

9 Megias, M., Crespi, M., 2003. A Kruppel-like transcription factor gene is involved in

10 salt stress responses in Medicago spp. Plant Soil 257, 1-9.

11 Merchan, F., de Lorenzo, L., Rizzo, S.G., Niebel, A., Manyani, H., Frugier, F., Sousa, 12 C., Crespi, M., 2007. Identification of regulatory pathways involved in the reacquisition 13 of root growth after salt stress in Medicago truncatula. Plant J. 51, 1-17.

14 Middleton, P.H., Jakab, J., Penmetsa, R.V., Starker, C.G., Doll, J., Kaló, P., Prabhu, R., 15 Marsh, J.F., Mitra, R.M., Kereszt, A., Dudas, B., VandenBosch, K., Long, S.R., Cook, 16 D.R., Kiss, G.B., Oldroyd, G.E.D., 2007. An ERF transcription factor in Medicago 17 truncatula that is essential for Nod factor signal transduction. Plant Cell 19, 1221-1234.

18 Mitra, R.M., Gleason, C.A., Edwards, A., Hadfield, J., Downie, J.A., Oldroyd, G.E.D.,

19 Long, S.R., 2004. A Ca ${ }^{2+} /$ calmodulin-dependent protein kinase required for symbiotic 20 nodule development: Gene identification by transcript-based cloning. Proc. Natl. Acad. 21 Sci. USA 101, 4701-4705.

22 Moussart, A., Onfroy, C., Lesne, A., Esquibet, M., Grenier, E., Tivoli, B., 2007. Host 23 status and reaction of Medicago truncatula accessions to infection by three major 24 pathogens of pea (Pisum sativum) and alfalfa (Medicago sativa). Eur. J. plant Pathol. $25 \quad 117,57-69$. 
1 Mudge, J., Cannon, S.B., Kaló, P., Oldroyd, G.E.D., Roe, B.A., Town, C.D., Young,

2 N.D., 2005. Highly syntenic regions in the genomes of soybean, Medicago truncatula,

3 and Arabidopsis thaliana. BMC Plant Biol. 5, 15.

4 Murray, J.D., Karas, B.J., Sato, S., Tabata, S., Amyot, L., Szczyglowski, K., 2007. A

5 cytokinin perception mutant colonized by Rhizobium in the absence of nodule

6 organogenesis. Science 315, 101-104.

7 Mytton, L.R., 1984. Developing a breeding strategy to exploit quantitative variation in 8 symbiotic nitrogen-fixation. Plant Soil 82, 329-335.

9 Mytton, L.R., Elsherbeeny, M.H., Lawes, D.A., 1977. Symbiotic variability in Vicia 10 faba. 3. Genetic effects of host plant, Rhizobium strain and of host X strain interaction. 11 Euphytica 26, 785-791.

12 Nam, Y.W., Penmetsa, R.V., Endre, G., Uribe, P., Kim, D., Cook, D.R., 1999.

13 Construction of a bacterial artificial chromosome library of Medicago truncatula and 14 identification of clones containing ethylene-response genes. Theor. Appl. Genet. 98, $15 \quad 638-646$.

16 Naya, L., Ladrera, R., Ramos, J., González, E.M., Arrese-Igor, C., Minchin, F.R., 17 Becana, M., 2007. The response of carbon metabolism and antioxidant defenses of 18 alfalfa nodules to drought stress and to the subsequent recovery of plants. Plant Physiol. $19 \quad 144,1104-1114$.

20 Nelson, M.N., Phan, H.T., Ellwood, S.R., Moolhuijzen, P.M., Hane, J., Williams, A., 21 O'Lone, C.E., Fosu-Nyarko, J., Scobie, M., Cakir, M., Jones, M.G., Bellgard, M., 22 Ksiazkiewicz, M., Wolko, B., Barker, S.J., Oliver, R.P., Cowling, W.A., 2006. The first 23 gene-based map of Lupinus angustifolius L.: Location of domestication genes and 24 conserved synteny with Medicago truncatula. Theor. Appl. Genet. 113, 225-238. 
1 Nishimura, R., Hayashi, M., Wu, G.J., Kouchi, H., Imaizumi-Anraku, H., Murakami,

2 Y., Kawasaki, S., Akao, S., Ohmori, M., Nagasawa, M., Harada, K., Kawaguchi, M.,

3 2002a. HAR1 mediates systemic regulation of symbiotic organ development. Nature

$4 \quad 420,426-429$.

5 Nishimura, R., Ohmori, M., Fujita, H., Kawaguchi, M., 2002b. A Lotus basic leucine

6 zipper protein with a RING-finger motif negatively regulates the developmental

7 program of nodulation. Proc. Natl. Acad. Sci. USA 99, 15206-15210.

8 Nunes, C., Araujo, S.D., da Silva, J.M., Fevereiro, M.P.S., da Silva, A.B., 2008.

9 Physiological responses of the legume model Medicago truncatula cv. Jemalong to

10 water deficit. Environ. Exp. Bot. 63, 289-296.

11 Nyamsuren, O., Colditz, F., Rosendahl, S., Tamasloukht, M., Bekel, T., Meyer, F.,

12 Küster, H., Franken, P., Krajinski, F., 2003. Transcriptional profiling of Medicago

13 truncatula roots after infection with Aphanomyces euteiches (oomycota) identifies novel

14 genes upregulated during this pathogenic interaction. Physiol. Mol. Plant Pathol. 63, 17-

1526 .

16 O'Neill, N.R., Bauchan, G.R., 2000. Sources of resistance to anthracnose in the annual

17 Medicago core collection. Plant Disease 84, 261-267.

18 O'Neill, N.R., Bauchan, G.R., Samac, D.A., 2003. Reactions in the annual Medicago

19 spp. core germ plasm collection to Phoma medicaginis. Plant Disease 87, 557-562.

20 Oka-Kira, E., Tateno, K., Miura, K., Haga, T., Hayashi, M., Harada, K., Sato, S.,

21 Tabata, S., Shikazono, N., Tanaka, A., Watanabe, Y., Fukuhara, I., Nagata, T.,

22 Kawaguchi, M., 2005. Klavier (klv), a novel hypernodulation mutant of Lotus japonicus

23 affected in vascular tissue organization and floral induction. Plant J. 44, 505-515.

24 Oldroyd, G.E.D., 2007. Nodules and hormones. Science 315, 52-53. 
1 Olsson, M., Nilsson, K., Liljenberg, C., Hendry, G.A.F., 1996. Drought stress in

2 seedlings: Lipid metabolism and lipid peroxidation during recovery from drought in

3 Lotus corniculatus and Cerastium fontanum. Physiol. Plant. 96, 577-584.

4 Paterson, A.H., Bowers, J.E., Burow, M.D., Draye, X., Elsik, C.G., Jiang, C.X., Katsar, 5 C.S., Lan, T.H., Lin, Y.R., Ming, R., Wright, R.J., 2000. Comparative genomics of 6 plant chromosomes. Plant Cell 12, 1523-1540.

7 Pedrosa, A., Sandal, N., Stougaard, J., Schweizer, D., Bachmair, A., 2002.

8 Chromosomal map of the model legume Lotus japonicus. Genetics 161, 1661-1672.

9 Penmetsa, R.V., Cook, D.R., 1997. A legume ethylene-insensitive mutant hyperinfected 10 by its rhizobial symbiont. Science $275,527-530$.

11 Penmetsa, R.V., Cook, D.R., 2000. Production and characterization of diverse 12 developmental mutants of Medicago truncatula. Plant Physiol. 123, 1387-1398.

13 Penmetsa, R.V., Uribe, P., Anderson, J., Lichtenzveig, J., Gish, J.C., Nam, Y.W., 14 Engstrom, E., Xu, K., Sckisel, G., Pereira, M., Baek, J.M., López-Meyer, M., Long, 15 S.R., Harrison, M.J., Singh, K.B., Kiss, G.B., Cook, D.R., 2008. The Medicago 16 truncatula ortholog of Arabidopsis EIN2, sickle, is a negative regulator of symbiotic 17 and pathogenic microbial associations. Plant J. 55, 580-595.

18 Perlick, A.M., Pühler, A., 1993. A survey of transcripts expressed specifically in root 19 nodules of broadbean (Vicia faba L). Plant Mol. Biol. 22, 957-970.

20 Perry, J.A., Wang, T.L., Welham, T.J., Gardner, S., Pike, J.M., Yoshida, S., Parniske, 21 M., 2003. A TILLING reverse genetic tool and a web-accessible collection of mutants 22 of the legume Lotus japonicus. Plant Physiol. 131, 866-871.

23 Phan, H.T.T., Ellwood, S.R., Ford, R., Thomas, S., Oliver, R., 2006. Differences in 24 syntenic complexity between Medicago truncatula with Lens culinaris and Lupinus 25 albus. Funct. Plant Biol. 33, 775-782. 
1 Phan, H.T., Ellwood, S.R., Adhikari, K., Nelson, M.N., Oliver, R.P., 2007. The first

2 genetic and comparative map of white lupin (Lupinus albus L.): Identification of QTLs

3 for anthracnose resistance and flowering time, and a locus for alkaloid content. DNA

4 Res. 14, 59-70.

5 Phinney, B.S., Thelen, J.J., 2005. Proteomic characterization of a triton-insoluble

6 fraction from chloroplasts defines a novel group of proteins associated with

7 macromolecular structures. J. Proteome Res. 4, 497-506.

8 Pierre, J.B., Huguet, T., Barre, P., Huyghe, C., Julier, B., 2008. Detection of QTLs for

9 flowering date in three mapping populations of the model legume species Medicago

10 truncatula. Theor. Appl. Genet. 117, 609-620.

11 Pilet-Nayel, M.L., Muehlbauer, F.J., McGee, R.J., Kraft, J.M., Baranger, A., Coyne,

12 C.J., 2005. Consistent quantitative trait loci in pea for partial resistance to Aphanomyces

13 euteiches isolates from the United States and France. Phytopathology 95, 1287-1293.

14 Plowright, R.A., Caubel, G., Mizen, K.A., 2002. Ditylenchus species. In: Starr, J.L.,

15 Cook, R., Bridge, J. (Eds.), Plant resistance to parasitic nematodes. CABI publishing, 16 pp. 107-139.

17 Poch, H.L., López, R.H., Clark, S.J., 2007. Ecotypes of the model legume Lotus 18 japonicus vary in their interaction phenotypes with the root-knot nematode 19 Meloidogyne incognita. Ann. Bot. 99, 1223-1229.

20 Postma, J.G., Jacobsen, E., Feenstra, W.J., 1988. Three pea mutants with an altered 21 nodulation studied by genetic analysis and grafting. J. Plant Physiol. 132, 424-430.

22 Poulsen, M.H., 1977. Obligate autogamy in Vicia faba L. J. Agric. Sci. (Camb.) 88, $23 \quad 253-256$.

24 Prats, E., Llamas, M.J., Rubiales, D., 2007. Characterization of resistance mechanisms 25 to Erysiphe pisi in Medicago truncatula. Phytopathology 97, 1049-1053. 
1 Prioul-Gervais, S., Deniot, G., Receveur, E.M., Frankewitz, A., Fourmann, M., Rameau,

2 C., Pilet-Nayel, M.L., Baranger, A., 2007. Candidate genes for quantitative resistance to

3 Mycosphaerella pinodes in pea (Pisum sativum L.). Theor. Appl. Genet. 114, 971-984.

4 Radutoiu, S., Madsen, L.H., Madsen, E.B., Felle, H.H., Umehara, Y., Gronlund, M.,

5 Sato, S., Nakamura, Y., Tabata, S., Sandal, N., Stougaard, J., 2003. Plant recognition of

6 symbiotic bacteria requires two LysM receptor-like kinases. Nature 425, 585-592.

7 Rech, E.L., Vianna, G.R., Aragao, F.J., 2008. High-efficiency transformation by

8 biolistics of soybean, common bean and cotton transgenic plants. Nat. Protoc. 3, 4109418.

10 Repetto, O., Rogniaux, H., Firnhaber, C., Zuber, H., Küster, H., Larre, C., Thompson, 11 R., Gallardo, K., 2008. Exploring the nuclear proteome of Medicago truncatula at the 12 switch towards seed filling. Plant J. 56, 398-410.

13 Ricoult, C., Cliquet, J.B., Limami, A.M., 2005. Stimulation of alanine amino transferase 14 (AlaAT) gene expression and alanine accumulation in embryo axis of the model legume 15 Medicago truncatula contribute to anoxia stress tolerance. Physiol. Plant. 123, 30-39.

16 Ricoult, C., Echeverria, L.O., Cliquet, J.B., Limami, A.M., 2006. Characterization of 17 alanine aminotransferase (AlaAT) multigene family and hypoxic response in young 18 seedlings of the model legume Medicago truncatula. J. Exp. Bot. 57, 3079-3089.

19 Rodriguez-Conde, M.F., Moreno, M.T., Cubero, J.I., Rubiales, D., 2004.

20 Characterization of the Orobanche-Medicago truncatula association for studying early 21 stages of the parasite-host interaction. Weed Res. 44, 218-223.

22 Román, B., Torres, A.M., Rubiales, D., Cubero, J.I., Satovic, Z., 2002. Mapping of 23 quantitative trait loci controlling broomrape (Orobanche crenata Forsk.) resistance in 24 faba bean (Vicia faba L.). Genome 45, 1057-1063. 
1 Román, B., Satovic, Z., Ávila, C.M., Rubiales, D., Moreno, M.T., Torres, A.M., 2003.

2 Locating genes associated with Ascochyta fabae resistance in Vicia faba. Austr. J.

3 Agric. Res. 54, 85-90.

4 Román, B., Satovic, Z., Pozarkova, D., Macas, J., Dolezel, J., Cubero, J.I., Torres,

5 A.M., 2004. Development of a composite map in Vicia faba, breeding applications and

6 future prospects. Theor. Appl. Genet. 108, 1079-1088.

7 Rose, R.J., 2008. Medicago truncatula as a model for understanding plant interactions

8 with other organisms, plant development and stress biology: Past, present and future.

9 Funct. Plant Biol. 35, 253-264.

10 Rubiales, D., Moral, A., 2004. Prehaustorial resistance against alfalfa rust (Uromyces

11 striatus) in Medicago truncatula. Eur. J. Plant Pathol. 110, 239-243.

12 Rubio, M.C., González, E.M., Minchin, F.R., Webb, K.J., Arrese-Igor, C., Ramos, J.,

13 Becana, M., 2002. Effects of water stress on antioxidant enzymes of leaves and nodules

14 of transgenic alfalfa overexpressing superoxide dismutases. Physiol. Plant. 115, 53115540.

16 Saito, K., Yoshikawa, M., Yano, K., Miwa, H., Uchida, H., Asamizu, E., Sato, S., 17 Tabata, S., Imaizumi-Anraku, H., Umehara, Y., Kouchi, H., Murooka, Y., 18 Szczyglowski, K., Downie, J.A., Parniske, M., Hayashi, M., Kawaguchi, M., 2007. 19 NUCLEOPORIN85 is required for calcium spiking, fungal and bacterial symbioses, and 20 seed production in Lotus japonicus. Plant Cell 19, 610-624.

21 Sanchez, D.H., Lippold, F., Redestig, H., Hannah, M.A., Erban, A., Kramer, U., Kopka, 22 J., Udvardi, M.K., 2008. Integrative functional genomics of salt acclimatization in the 23 model legume Lotus japonicus. Plant J. 53, 973-987.

24 Sandal, N., Petersen, T.R., Murray, J., Umehara, Y., Karas, B., Yano, K., Kumagai, H., 25 Yoshikawa, M., Saito, K., Hayashi, M., Murakami, Y., Wang, X., Hakoyama, T., 
1 Imaizumi-Anraku, H., Sato, S., Kato, T., Chen, W., Hossain, M.S., Shibata, S., Wang,

2 T., Yokota, K., Larsen, K., Kanamori, N., Madsen, E., Radutoiu, S., Madsen, L.H.,

3 Radu, T.G., Krusell, L., Ooki, Y., Banba, M., Betti, M., Rispail, N., Skøt, L., Tuck, E.,

4 Perry, J., Yoshida, S., Vickers, K., Pike, J., Mulder, L., Charpentier, M., Müller, J.,

5 Ohtomi, R., Kojima, T., Ando, S., Márquez, A.J., Gresshoff, P.M., Harada, K., Webb,

6 K.J., Hata, S., Suganuma, N., Kouchi, H., Kawasaki, S., Tabata, S., Hayashi, M.,

7 Parniske, M., Szczyglowski, K., Kawaguchi, M., Stougaard, J., 2006. Genetics of

8 symbiosis in Lotus japonicus: Recombinant inbred lines, comparative genetic maps and

9 map position of 36 symbiotic loci. Mol. Plant Microbe Interac. 19, 80-91.

10 Sato, S., Nakamura, Y., Asamizu, E., Isobe, S., Tabata, S., 2007. Genome sequencing 11 and genome resources in model legumes. Plant Physiol. 144, 588-593.

12 Sato, S., Nakamura, Y., Kaneko, T., Asamizu, E., Kato, T., Nakao, M., Sasamoto, S., 13 Watanabe, A., Ono, A., Kawashima, K., Fujishiro, T., Katoh, M., Kohara, M., Kishida, 14 Y., Minami, C., Nakayama, S., Nakazaki, N., Shimizu, Y., Shinpo, S., Takahashi, C., 15 Wada, T., Yamada, M., Ohmido, N., Hayashi, M., Fukui, K., Baba, T., Nakamichi, T., 16 Mori, H., Tabata, S., 2008. Genome structure of the legume Lotus japonicus. DNA Res. $17 \quad 15,227-239$.

18 Schauser, L., Roussis, A., Stiller, J., Stougaard, J., 1999. A plant regulator controlling 19 development of symbiotic root nodules. Nature 402, 191-195.

20 Schiltz, S., Gallardo, K., Huart, M., Negroni, L., Sommerer, N., Burstin, J., 2004.

21 Proteome reference maps of vegetative tissues in pea. An investigation of nitrogen 22 mobilization from leaves during seed filling. Plant Physiol. 135, 2241-2260.

23 Schnabel, E., Journet, E.P., de Carvalho-Niebel, F., Duc, G., Frugoli, J., 2005. The Medicago truncatula SUNN gene encodes a CLV1-like leucine-rich repeat receptor

25 kinase that regulates nodule number and root length. Plant Mol. Biol. 58, 809-822. 
1 Schröder, G., Frühling, M., Pühler, A., Perlick, A.M., 1997. The temporal and spatial

2 transcription pattern in root nodules of Vicia faba nodulin genes encoding glycine-rich

3 proteins. Plant Mol. Biol. 33, 113-123.

4 Schumpp, O., Ramel, M.E., Gugerli, P., Broughton, W.J., Deakin, W.J., 2007.

5 Identification of a Lotus viral pathogen. J. Plant Res. 120, 651-654.

6 Searle, I.R., Men, A.E., Laniya, T.S., Buzás, D.M., Iturbe-Ormaetxe, I., Carroll, B.J.,

7 Gresshoff, P.M., 2003. Long-distance signaling in nodulation directed by a

8 CLAVATA1-like receptor kinase. Science 299, 109-112.

9 Shimoda, Y., Nagata, M., Suzuki, A., Abe, M., Sato, S., Kato, T., Tabata, S., Higashi,

10 S., Uchiumi, T., 2005. Symbiotic rhizobium and nitric oxide induce gene expression of

11 non-symbiotic hemoglobin in Lotus japonicus. Plant Cell Physiol. 46, 99-107.

12 Shimoda, Y., Shimoda-Sasakura, F., Kucho, K.I., Kanamori, N., Nagata, M., Suzuki,

13 A., Abe, M., Higashi, S., Uchiumi, T., 2008. Overexpression of class 1 plant

14 hemoglobin genes enhances symbiotic nitrogen fixation activity between

15 Mesorhizobium loti and Lotus japonicus. Plant J. 57, 254-263.

16 Simon, C.J., Muehlbauer, F.J., 1997. Construction of a chickpea linkage map and its

17 comparison with maps of pea and lentil. J. Heredity 88, 115-119.

18 Smit, P., Raedts, J., Portyanko, V., Debellé, F., Gough, C., Bisseling, T., Geurts, R.,

19 2005. NSP1 of the GRAS protein family is essential for rhizobial Nod factor-induced

20 transcription. Science 308, 1789-1791.

21 Stacey, G., Libault, M., Brechenmacher, L., Wan, J., May, G.D., 2006. Genetics and 22 functional genomics of legume nodulation. Curr. Opin. Plant Biol. 9, 110-121.

23 Stracke, S., Kistner, C., Yoshida, S., Mulder, L., Sato, S., Kaneko, T., Tabata, S.,

24 Sandal, N., Stougaard, J., Szczyglowski, K., Parniske, M., 2002. A plant receptor-like

25 kinase required for both bacterial and fungal symbiosis. Nature 417, 959-962. 
1 Stracke, S., Sato, S., Sandal, N., Koyama, M., Kaneko, T., Tabata, S., Parniske, M.,

2 2004. Exploitation of colinear relationships between the genomes of Lotus japonicus,

3 Pisum sativum and Arabidopsis thaliana, for positional cloning of a legume symbiosis

4 gene. Theor. Appl. Genet. 108, 442-449.

5 Subramanian, S., Graham, M.Y., Yu, O., Graham, T.L., 2005. RNA interference of 6 soybean isoflavone synthase genes leads to silencing in tissues distal to the 7 transformation site and to enhanced susceptibility to Phytophthora sojae. Plant Physiol. $8 \quad 137,1345-1353$.

9 Swindell, W.R., Huebner, M., Weber, A.P., 2007. Transcriptional profiling of 10 Arabidopsis heat shock proteins and transcription factors reveals extensive overlap 11 between heat and non-heat stress response pathways. BMC Genomics 8 .

12 Tadege, M., Wen, J., He, J., Tu, H., Kwak, Y., Eschstruth, A., Cayrel, A., Endre, G., 13 Zhao, P.X., Chabaud, M., Ratet, P., Mysore, K.S., 2008. Large-scale insertional 14 mutagenesis using the Tnt1 retrotransposon in the model legume Medicago truncatula. 15 Plant J. 54, 335-347.

16 Tar'an, B., Warkentin, T., Somers, D.J., Miranda, D., Vandenburg, A., Blade, S., 17 Woods, S., Bing, D., Xue, A., DeKoeyer, D., Penner, G., 2003. Quantitative trait loci 18 for lodging resistance, plant height and partial resistance to mycosphaerella blight in 19 field pea (Pisum sativum L.). Theor. Appl. Genet. 107, 1482-1491.

20 Tar'an, B., Warkentin, T., Somers, D.J., Miranda, D., Vandenberg, A., Blade, S., Bing, 21 D., 2004. Identification of quantitative trait loci for grain yield, seed protein 22 concentration and maturity in field pea (Pisum sativum L.). Euphytica 136, 297-306.

23 Tivoli, B., Baranger, A., Sivasithamparam, K., Barbetti, M.J., 2006. Annual Medicago:

24 From a model crop challenged by a spectrum of necrotrophic pathogens to a model 25 plant to explore the nature of disease resistance. Ann. Bot. 98, 1117-1128. 
1 Thomashow, M.F., 1999. Plant cold acclimation: Freezing tolerance genes and

2 regulatory mechanisms. Annu. Rev. Plant Phys. 50, 571-599.

3 Thompson, R., Ratet, P., Küster, H., 2005. Identification of gene functions by applying

4 TILLING and insertional mutagenesis strategies on microarray-based expression data.

5 Grain Legumes Magazine, pp. 20-22.

6 Thoquet, P., Ghérardi, M., Journet, E.P., Kereszt, A., Ané, J.M., Prosperi, J.M., Huguet,

7 T., 2002. The molecular genetic linkage map of the model legume Medicago truncatula:

8 an essential tool for comparative legume genomics and the isolation of agronomically

9 important genes. BMC Plant Biol. 2, 1.

10 Thykjaer, T., Stiller, J., Handberg, K., Jones, J., Stougaard, J., 1995. The maize

11 transposable element Ac is mobile in the legume Lotus japonicus. Plant Mol. Biol. 27,

$12981-993$.

13 Timmerman-Vaughan, G.M., Mills, A., Whitfield, C., Frew, T., Butler, R., Murray, S.,

14 Lakeman, M., McCallum, J., Russell, A., Wilson, D., 2005. Linkage mapping of QTL

15 for seed yield, yield components, and developmental traits in pea. Crop Sci. 45, 1336-

161344.

17 Tirichine, L., Sandal, N., Madsen, L.H., Radutoiu, S., Albrektsen, A.S., Sato, S., 18 Asamizu, E., Tabata, S., Stougaard, J., 2007. A gain-of-function mutation in a cytokinin 19 receptor triggers spontaneous root nodule organogenesis. Science 315, 104-107.

20 Torregrosa, C., Cluzet, S., Fournier, J., Huguet, T., Gamas, P., Prosperi, J.M., Esquerre-

21 Tugaye, M.T., Dumas, B., Jacquet, C., 2004. Cytological, genetic, and molecular 22 analysis to characterize compatible and incompatible interactions between Medicago truncatula and Colletotrichum trifolii. Mol. Plant Microbe Interac. 17, 909-920. 
1 Tougou, M., Yamagishi, N., Furutani, N., Shizukawa, Y., Takahata, Y., Hidaka, S.,

2 2007. Soybean dwarf virus-resistant transgenic soybeans with the sense coat protein

3 gene. Plant Cell Rep. 26, 1967-1975.

4 Tramontano, W.A., Jouve, D., 1997. Trigonelline accumulation in salt-stressed legumes

5 and the role of other osmoregulators as cell cycle control agents. Phytochemistry 44,

$6 \quad 1037-1040$.

7 Trinchant, J.C., Boscari, A., Spermato, G., Van de Sype, G., Le Rudulier, D., 2004.

8 Proline betaine accumulation and metabolism in alfalfa plants under sodium chloride

9 stress. Exploring its compartmentalization in nodules. Plant Physiol. 135, 1583-1594.

10 Vailleau, F., Sartorel, E., Jardinaud, M.F., Chardon, F., Genin, S., Huguet, T.,

11 Gentzbittel, L., Petitprez, M., 2007. Characterization of the interaction between the

12 bacterial wilt pathogen Ralstonia solanacearum and the model legume plant Medicago

13 truncatula. Mol. Plant Microbe Interac. 20, 159-167.

14 Valot, B., Negroni, L., Zivy, M., Gianinazzi, S., Dumas-Gaudot, E., 2006. A mass

15 spectrometric approach to identify arbuscular mycorrhiza-related proteins in root

16 plasma membrane fractions. Proteomics 6 Suppl. 1, S145-155.

17 van Hengel, A.J., Barber, C., Roberts, K., 2004. The expression patterns of 18 arabinogalactan-protein AtAGP30 and GLABRA2 reveal a role for abscisic acid in the 19 early stages of root epidermal patterning. Plant J. 39, 70-83.

20 van Noorden, G.E., Kerim, T., Goffard, N., Wiblin, R., Pellerone, F.I., Rolfe, B.G.,

21 Mathesius, U., 2007. Overlap of proteome changes in Medicago truncatula in response

22 to auxin and Sinorhizobium meliloti. Plant Physiol. 144, 1115-1131.

23 Vavilov, N., 1922. The law of homologous series in variation. J. Genet. 12, 47-88. 
1 Vaz Patto, M.C., Torres, A.M., Koblizkova, A., Macas, J., Cubero, J.I., 1999.

2 Development of a genetic composite map of Vicia faba using F-2 populations derived

3 from trisomic plants. Theor. Appl. Genet. 98, 736-743.

4 Verdier, J., Kakar, K., Gallardo, K., Le Signor, C., Aubert, G., Schlereth, A., Town, 5 C.D., Udvardi, M.K., Thompson, R.D., 2008. Gene expression profiling of $M$. 6 truncatula transcription factors identifies putative regulators of grain legume seed $7 \quad$ filling. Plant Mol. Biol. 67, 567-580.

8 Verdoy, D., Coba De La Pena, T., Redondo, F.J., Lucas, M.M., Pueyo, J.J., 2006.

9 Transgenic Medicago truncatula plants that accumulate proline display nitrogen-fixing

10 activity with enhanced tolerance to osmotic stress. Plant Cell Environ. 29, 1913-1923.

11 Vernié, T., Moreau, S., de Billy, F., Plet, J., Combier, J.P., Rogers, C., Oldroyd, G., 12 Frugier, F., Niebel, A., Gamas, P., 2008. EFD is an ERF transcription factor involved in 13 the control of nodule number and differentiation in Medicago truncatula. Plant Cell 20, $14 \quad 2693-2713$.

15 Vieweg, M.F., Frühling, M., Quandt, H.J., Heim, U., Bäumlein, H., Pühler, A., Küster, 16 H., Andreas, M.P., 2004. The promoter of the Vicia faba L. leghemoglobin gene 17 VfLb29 is specifically activated in the infected cells of root nodules and in the 18 arbuscule-containing cells of mycorrhizal roots from different legume and non legume 19 plants. Mol. Plant Microbe Interac. 17, 62-69.

20 Wang, X., Sato, S., Tabata, S., Kawasaki, S., 2008. A high-density linkage map of Lotus 21 japonicus based on AFLP and SSR markers. DNA Res. 15, 323-332.

22 Watson, B.S., Asirvatham, V.S., Wang, L., Sumner, L.W., 2003. Mapping the proteome 23 of barrel medic (Medicago truncatula). Plant Physiol. 131, 1104-1123.

24 Webb, K.J., Skøt, L., Nicholson, M.N., Jorgensen, B., Mizen, S., 2000. Mesorhizobium 25 loti increases root-specific expression of a calcium-binding protein homologue 
1 identified by promoter tagging in Lotus japonicus. Mol. Plant Microbe Interac. 13, 6062616

3 Weeden, N.F., Muehlbauer, F.J., Ladizinsky, G., 1992. Extensive conservation of

4 linkage relationships between pea and lentil genetic maps. J. Heredity 83, 123-129.

5 Weeden, N.F., Ellis, T.H.N., Timmerman-Vaughan, G.M., Swiecicki, W.K., Rozov, 6 S.M., Berdnikov, V.A., 1998. A consensus linkage map for Pisum sativum. Pisum 7 Genetic 30, 1-4.

8 Weerasinghe, R.R., Bird, D.M., Allen, N.S., 2005. Root-knot nematodes and bacterial

9 Nod factors elicit common signal transduction events in Lotus japonicus. Proc. Natl. 10 Acad. Sci. USA 102, 3147-3152.

11 Weigelt, K., Küster, H., Radchuk, R., Müller, M., Weichert, H., Fait, A., Fernie, A.R., 12 Saalbach, I., Weber, H., 2008. Increasing amino acid supply in pea embryos reveals 13 specific interactions of $\mathrm{N}$ and $\mathrm{C}$ metabolism, and highlights the importance of 14 mitochondrial metabolism. Plant J. 55, 909-926.

15 Wesley, S.V., Helliwell, C.A., Smith, N.A., Wang, M.B., Rouse, D.T., Liu, Q., 16 Gooding, P.S., Singh, S.P., Abbott, D., Stoutjesdijk, P.A., Robinson, S.P., Gleave, A.P., 17 Green, A.G., Waterhouse, P.M., 2001. Construct design for efficient, effective and high18 throughput gene silencing in plants. Plant J. 27, 581-590.

19 Wienkoop, S., Saalbach, G., 2003. Proteome analysis. Novel proteins identified at the 20 peribacteroid membrane from Lotus japonicus root nodules. Plant Physiol. 131, 1080211090.

22 Winicov, I., Bastola, D.R., 1999. Transgenic overexpression of the transcription factor 23 Alfin1 enhances expression of the endogenous MsPRP2 gene in alfalfa and improves 24 salinity tolerance of the plants. Plant Physiol. 120, 473-480. 
1 Wu, F., Mueller, L.A., Crouzillat, D., Petiard, V., Tanksley, S.D., 2006. Combining

2 bioinformatics and phylogenetics to identify large sets of single-copy orthologous genes

3 (COSII) for comparative, evolutionary and systematic studies: A test case in the

4 euasterid plant clade. Genetics 174, 1407-1420.

5 Xu, Y., Ma, Q.H., 2004. Medicago truncatula Mt-ZFP1 encoding a root enhanced zinc

6 finger protein is regulated by cytokinin, abscisic acid and jasmonate, but not cold. DNA

7 Seq. $15,104-109$.

8 Yaege, J.R., Stuteville, D.L., 2000. Reactions in the annual Medicago core germ plasm

9 collection to two isolates of Peronospora trifoliorum from alfalfa. Plant Disease 84, $10 \quad 521-524$.

11 Yamada, K., Shimada, T., Kondo, M., Nishimura, M., Hara-Nishimura, I., 1999.

12 Multiple functional proteins are produced by cleaving Asn-Gln bonds of a single

13 precursor by vacuolar processing enzyme. J. Biol. Chem. 274, 2563-2570.

14 Yamaguchi, T., Blumwald, E., 2005. Developing salt-tolerant crop plants: Challenges

15 and opportunities. Trends Plant Sci. 10, 615-620.

16 Yang, S., Gao, M., Deshpande, S., Lin, S., Roe, B.A., Zhu, H., 2007. Genetic and 17 physical localization of an anthracnose resistance gene in Medicago truncatula. Theor. 18 Appl. Genet. 116, 45-52.

19 Yang, S., Gao, M., Xu, C., Gao, J., Deshpande, S., Lin, S., Roe, B.A., Zhu, H., 2008.

20 Alfalfa benefits from Medicago truncatula: The RCT1 gene from M. truncatula confers

21 broad-spectrum resistance to anthracnose in alfalfa. Proc. Natl. Acad. Sci. USA 105, $22 \quad 12164-12169$.

23 Zhang, C.Q., Ghabrial, S.A., 2006. Development of bean pod mottle virus-based vectors

24 for stable protein expression and sequence-specific virus-induced gene silencing in 25 soybean. Virology 344, 401-411. 
1 Zhang, J.Y., Broeckling, C.D., Blancaflor, E.B., Sledge, M.K., Sumner, L.W., Wang,

2 Z.Y., 2005. Overexpression of WXP1, a putative Medicago truncatula AP2 domain3 containing transcription factor gene, increases cuticular wax accumulation and enhances

4 drought tolerance in transgenic alfalfa (Medicago sativa). Plant J. 42, 689-707.

5 Zhu, H., Choi, H.K., Cook, D.R., Shoemaker, R.C., 2005. Bridging model and crop 6 legumes through comparative genomics. Plant Physiol. 137, 1189-1196.

7 


\section{Tables}

2 Table 1. Comparison of genome size, seed composition and available resources between Vicia faba, 3 Pisum sativum and Medicago truncatula. Phylogeny for the species according to Choi et al. (2004a) is 4 represented as a tree on the left.

\begin{tabular}{|c|c|c|c|c|c|c|}
\hline Species & $\begin{array}{l}\text { Genome } \\
\text { size } \\
(\mathrm{Mb})\end{array}$ & 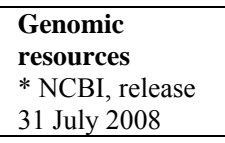 & Genetic resources & QTL mapping & 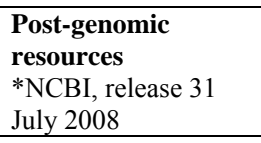 & Seed composition \\
\hline $\begin{array}{l}\text { Vicia faba } \\
\text { Tribe } \\
\text { Viceae }\end{array}$ & $\begin{array}{l}\sim \mathbf{1 3 , 0 0 0} \\
(2 \mathrm{n}=12 \\
\text { chrom. })\end{array}$ & $\begin{array}{l}\begin{array}{l}466 \text { core } \\
\text { nucleotide } \\
\text { sequences * }\end{array} \\
\begin{array}{l}512 \text { genome } \\
\text { survey } \\
\text { sequences* }\end{array}\end{array}$ & $\begin{array}{l}\text { Mapping populations and } \\
\text { linkage maps: } \\
\text { - 20 F2 populations } \\
\text { - } 14 \text { major linkage groups } \\
\text { Vaz Patto et al. 1999; Ávila } \\
\text { et al. 2003, 2004; Román et } \\
\text { al. } 2004 \text { and references } \\
\text { therein } \\
\text { Vicia faba germplasm } \\
\text { collections at: } \\
\text { - http://193.50.15.18/legumbase// } \\
\text { - http://www.icarda.cgiar.org/ }\end{array}$ & $\begin{array}{l}\text { QTL mapped for } \\
\text { seed weight and } \\
\text { disease resistance } \\
\text { Vaz Patto et al. } \\
\text { 1999; Ávila et al. } \\
\text { 2004; Román et } \\
\text { al. 2002, } 2003\end{array}$ & $<10 \mathrm{EST}^{*}$ & $\begin{array}{l}1 \mathrm{~cm} \\
30 \% \text { proteins } \\
42 \% \text { starch } \\
2 \% \text { lipids } \\
9 \% \text { cellulose } \\
4 \% \text { soluble sugars } \\
\text { (Duc et al., } 1999 \text { ) }\end{array}$ \\
\hline $\begin{array}{l}\text { Pisum } \\
\text { sativum } \\
\text { Tribe } \\
\text { Viceae }\end{array}$ & $\begin{array}{l}\sim 5,000 \\
(2 \mathrm{n}=14 \\
\text { chrom.) }\end{array}$ & $\begin{array}{l}\text { 3,864 core } \\
\text { nucleotide } \\
\text { sequences* } \\
\text { 154 genome } \\
\text { survey } \\
\text { sequences* } \\
\text { BAC libraries: } \\
\text { - Line PI269818: } \\
\sim 3 \text { genome } \\
\text { equivalents } \\
\text { (Coyne et al., } \\
\text { 2007) } \\
\text { - Cv. Caméor: } \\
\sim 10 \text { genome } \\
\text { equivalents (A. } \\
\text { Bendahmane, } \\
\text { personal } \\
\text { communication) }\end{array}$ & $\begin{array}{l}\text { Mapping populations and } \\
\text { linkage maps: } \\
\text { - } 20 \text { population (F2, F5 to } \\
\text { F9) } \\
\text { - } 7 \text { linkage groups } \\
\text { (Weeden et al., 1998; Ellis } \\
\text { and Poyser } 2002 \text {; Tar'an et } \\
\text { al., 2003; Loridon et al., } \\
\text { 2005; Pilet-Nayel et al., } \\
\text { 2005; Aubert et al., 2006) } \\
\text { Pea germplasm collections: } \\
\text { - http://193.50.15.18/legumbase/ } \\
\text {-http://www.jic.ac.uk/germplas/pi } \\
\text { sum/; www.ars-grin.gov/ } \\
\text { Mutant populations: } \\
\text { TILLING (Dalmais et al., } \\
\text { 2008) }\end{array}$ & $\begin{array}{l}\text { QTL mapped for } \\
\text { a range of } \\
\text { agronomic traits } \\
\text { e.g. seed traits, } \\
\text { disease resistance, } \\
\text { frost tolerance } \\
\text { (Tar'an et al., } \\
\text { 2004; Pilet-Nayel } \\
\text { et al., 2005; } \\
\text { Timmermann- } \\
\text { Vaughan et al., } \\
\text { 2005; Burstin et } \\
\text { al., 2007; Prioul- } \\
\text { Gervais et al., } \\
\text { 2007; Lejeune- } \\
\text { Hénaut et al., } \\
\text { 2008) }\end{array}$ & $\begin{array}{l}\text { EST count : } \\
6,327 \text { ESTs* } \\
\text { (580 from seed } \\
\text { cDNA libraries) } \\
\text { Transcriptomics : } \\
\text { Ps6kOLI1 } \\
\text { microarrays } \\
\text { (Weigelt et al., 2008) } \\
\text { Proteome maps : } \\
\text { e.g. leaves (Schiltz et } \\
\text { al., 2004), mature } \\
\text { seeds (Bourgeois et } \\
\text { al., 2008), and } \\
\text { organelles (Bardel et } \\
\text { al., 2002; Phinney } \\
\text { and Thelen 2005) }\end{array}$ & $\begin{array}{l}\text { 23\% proteins } \\
50 \% \text { starch } \\
2 \% \text { lipids } \\
7 \% \text { cellulose } \\
5 \% \text { soluble sugars } \\
\text { (Bastianelli et al., } \\
1998 \text { ) }\end{array}$ \\
\hline $\begin{array}{l}\begin{array}{l}\text { Medicago } \\
\text { truncatula }\end{array} \\
\text { Tribe } \\
\text { Trifolieae }\end{array}$ & $\begin{array}{l}\sim 500 \\
(2 \mathrm{n}=16 \\
\text { chrom. })\end{array}$ & $\begin{array}{l}\begin{array}{l}\mathbf{6 , 1 4 9} \text { core } \\
\text { nucleotide } \\
\text { sequences * }\end{array} \\
\mathbf{1 6 8 , 8 1 5} \text { genome } \\
\text { survey } \\
\text { sequences* } \\
\text { BAC libraries: } \\
5 \text { to } 20 \text { genome } \\
\text { equivalents } \\
\text { (Nam et al., } \\
\text { 1999; Choi et al., } \\
\text { 2004a) } \\
\text { Sequencing } \\
\text { gene-rich regions } \\
\text { http://www.medica } \\
\text { go.org/genome/ }\end{array}$ & $\begin{array}{l}\text { Mapping populations and } \\
\text { linkage maps: } \\
\text { - 800 populations, } \\
\text { including five F6 to F7 } \\
\text { populations of } \\
\text { recombinant inbred lines } \\
\text { - } 8 \text { linkage groups } \\
\text { (Thoquet et al., } 2002 \text {; Green } \\
\text { et al., 2006) } \\
\text { M. truncatula germplasm } \\
\text { collections: } \\
\text { (Greene et al., 2006) } \\
\text { Mutant populations: } \\
\text { - TILLING (Thompson et } \\
\text { al. 2005), } \\
\text { - Tnt1 insertion (Tadege et } \\
\text { al. 2008) }\end{array}$ & $\begin{array}{l}\text { QTL mapped for } \\
\text { aerial } \\
\text { morphogenesis, } \\
\text { including } \\
\text { flowering, } \\
\text { resistance to } \\
\text { disease, spring } \\
\text { black stem and } \\
\text { leaf spot } \\
\\
\text { (Julier et al., } \\
2007 \text {; Vailleau et } \\
\text { al., 2007; } \\
\text { Ameline- } \\
\text { Torregrosa et al., } \\
\text { 2008; Kamphuis } \\
\text { et al., 2008; } \\
\text { Pierre et al., 2008) }\end{array}$ & $\begin{array}{l}\text { EST count: } \\
\text { 249,625 ESTs* } \\
\text { (12,937 from seed } \\
\text { cDNA libraries) } \\
\text { Transcriptomics : } \\
\text { Mt16kOLI1 } \\
\text { microarrays } \\
\text { (Hohnjec et al., 2005) } \\
\text { Affymetrix Medicago } \\
\text { GeneChip (Gene } \\
\text { expression atlas from } \\
\text { Benedito et al., 2008) } \\
\\
\text { Proteome } \\
\text { maps from various } \\
\text { tissues, including } \\
\text { seeds: } \\
\text { (Watson et al., 2003) }\end{array}$ & $\begin{array}{l}\text {. } \\
1 \mathrm{~cm} \\
6 \% \text { proteins } \\
1 \% \text { starch } \\
13 \% \text { lipids } \\
5 \% \text { cellulose } \\
5 \% \text { soluble sugars } \\
\text { (Duc, } 2004 \text { ) }\end{array}$ \\
\hline
\end{tabular}




\section{Figure legends}

2

3 Figure 1. Large-scale synteny blocks between M. truncatula (Mt) and L. japonicus (Lj)

4 chromosomes. Synteny was detected along entire chromosomal segments in the case of

5 M. truncatula chr 1 and L. japonicus chr 5, while rearrangements of colinear blocks in

6 other chromosomal regions resulted in a difference of chromosome number between the

7 two species. Bars with the same color or pattern show homologous chromosomal

8 regions and arrows in the boxes indicate the orientation of the chromosomes (short arm

$9-$ long arm). Blank boxes represent genomic regions where the correspondence between

10 the chromosomes has not yet been revealed clearly.

11 Figure 2. Signaling of nodulation. A. Nodulation factor perception leads to infection

12 and cell division in legume roots. NF signal transduction occurs through four

13 biochemical stages, beginning with receptor kinases, then membrane channels causing

14 calcium oscillations, followed by a protein kinase modulator (CCaMK) and a cytokinin

15 receptor, and finally through transcription factor control of diverse genetic pathways.

16 This cascade occurs in different cell layers of the root. For example, NF perception

17 likely occurs primarily in the root hair and the epidermis, perhaps fractionally so in the

18 cortex. Note that epidermal and root hair cells do not divide and hence there is a need

19 for a secondary signal to travel to the root interior and the pericycle, the target tissue for

20 nodule growth. Later parts of the cascade involving transcription factors may be

21 localized to this region. Detailed spatial analysis using gene fusions and reporter genes

22 is needed to elucidate such events. B. Autoregulation of Nodulation (AON) controls

23 nodule number by a systemic regulatory circuit involving root-shoot communication.

24 NF perception leads to an activated state closely associated with the induction of cell

25 divisions. This process may be mimicked by mycorrhizal fungi, which undergo 
1 eukaryotic cell cycle progression similar to that of plant cells (cf., Meixner et al, 2007).

2 This activated state is 'reinforced' by successful invasion and nitrogen fixation. The

3 mobile ' $Q$ ' signal is perceived by leaf tissues to release a putative ligand peptide that

4 interacts with the NARK receptor kinase in the phloem parenchyma of the leaf. NARK

5 is known to down-regulate several genes in the octadecanoid pathway leading to the

6 synthesis of jasmonic acid (JA). Metabolites related to this pathway or parallel targets

7 of NARK, including 'SDI', are presumed to migrate via the phloem to the developing

8 nodule primordium, blocking further nodule development. In temperate legumes, such

9 as pea and $M$. truncatula, this blockage occurs earlier than in the determinate-

10 nodulating soybean (Mathews et al., 1989).

11

12

13

14

15

16

17

18

19

20

21

22

23

24

25 
2 Figure 1

3
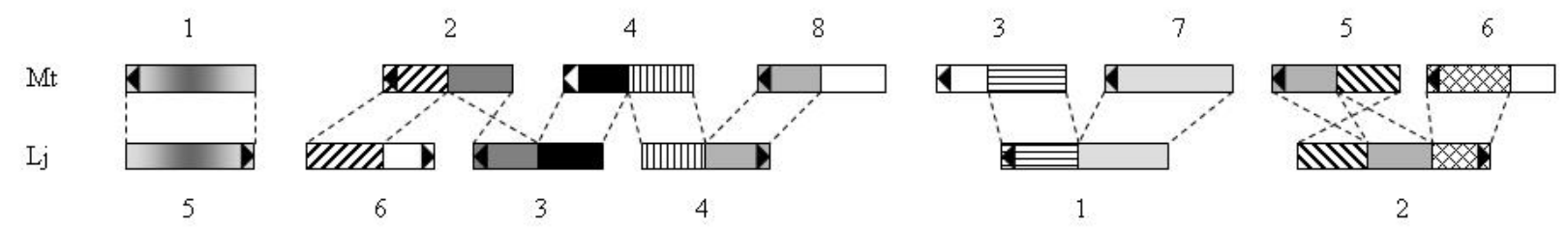

10

11

12

13

14

15

16

17

18

19

20

21

22

23

24

25 
$1 \quad$ Figure 2

2

3

4

5

6

7

8

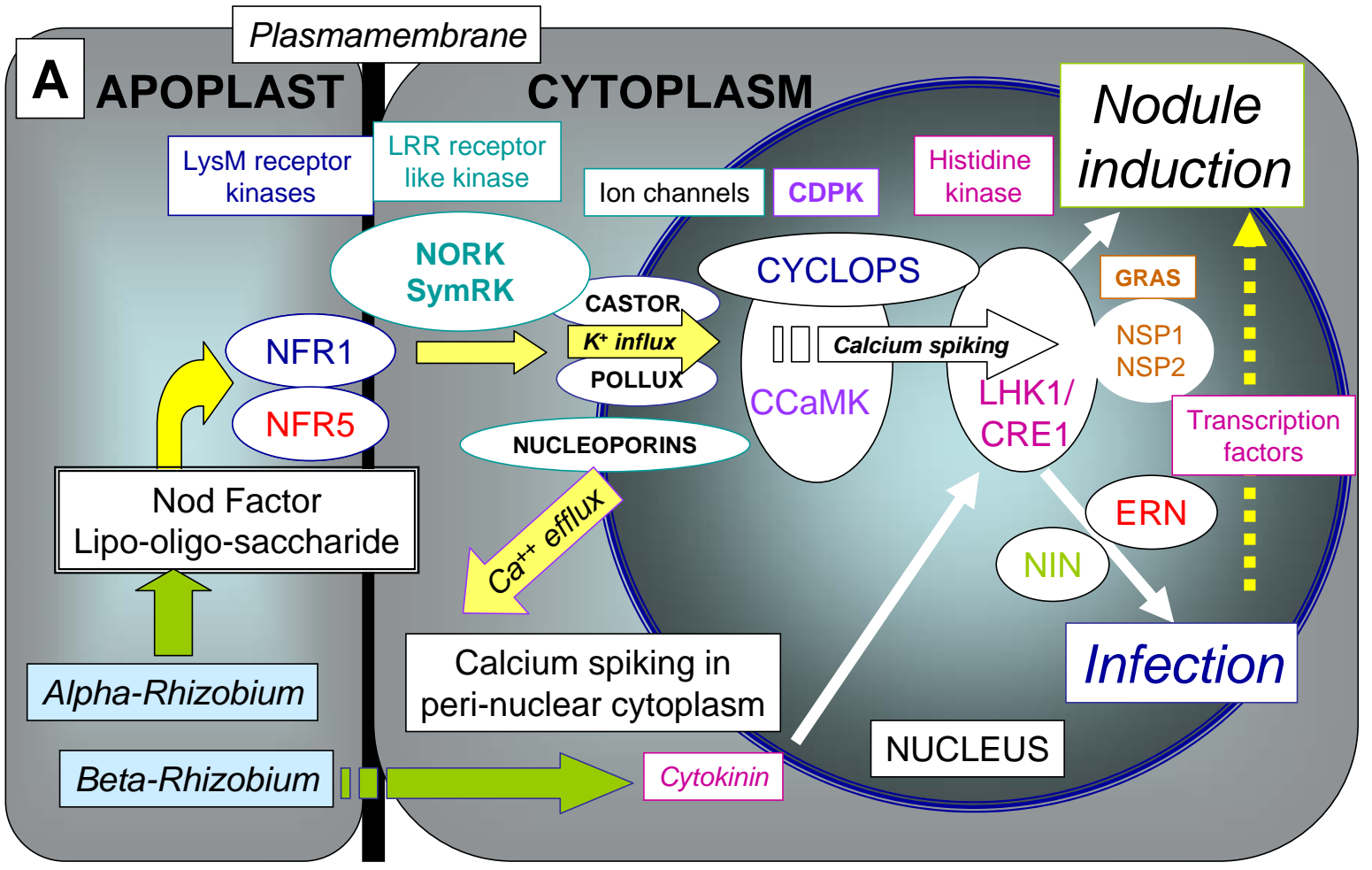

14

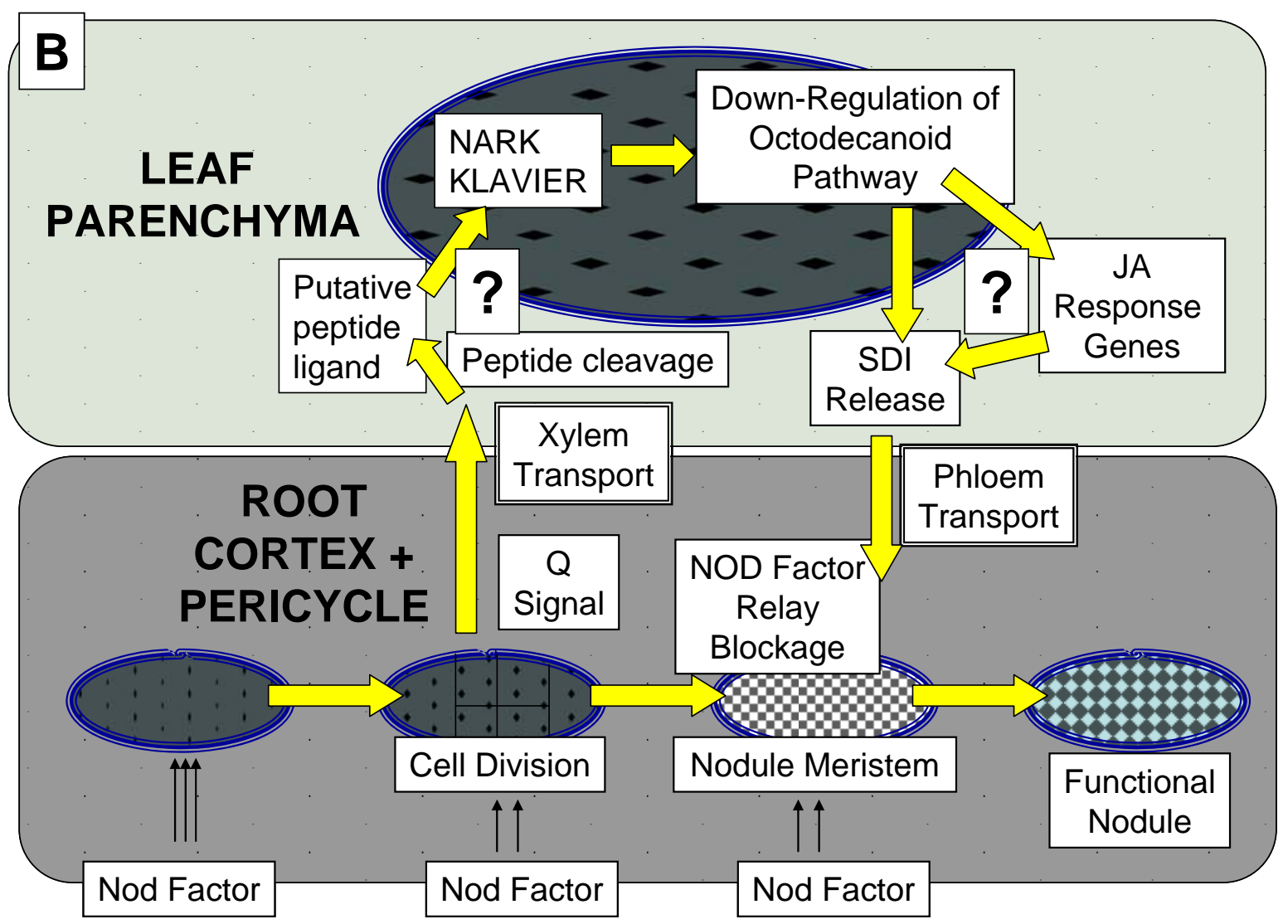

